\title{
ЭФФЕКТЫ СЕЙСМИЧЕСКИХ ВОЛН В ИЗМЕНЕНИЯХ УРОВНЯ ВОДЫ В СКВАЖИНЕ: ЭКСПЕРИМЕНТАЛЬНЫЕ ДАННЫЕ И МОДЕЛИ
}

\author{
(C) 2020 г. Г. Н. Копылова ${ }^{1, ~ *, ~ С . ~ В . ~ Б о л д и н а ~}{ }^{1, ~ * *}$ \\ ${ }^{1}$ Камчатский филиал Федерального исследовательского центра “Единая геофизическая служба РАН”, \\ г. Петропавловск-Камчатский, Россия \\ *E-mail:gala@emsd.ru \\ **E-mail: boldina@emsd.ru \\ Поступила в редакцию 13.03.2019 г. \\ После доработки 08.07.2019 г. \\ Принята к публикации 07.10.2019 г.
}

\begin{abstract}
В скважине Ю3-5, Камчатка, в 1996-2017 гг. проводились прецизионные измерения уровня воды с периодичностью 5-10 мин. В полученном ряду данных выделены вариации уровня воды, вызванные прохождением сейсмических волн (гидрогеосейсмические вариации - ГГСВ) при 19-ти землетрясениях с $M_{w}=6.8-9.1$, произошедших на эпицентральных расстояниях 80-14.6 тыс. км. С учетом морфологических особенностей ГГСВ выделены четыре их основных типа: колебания (I), наложение на колебания кратковременных (до десятков часов) повышений уровня воды (II), кратковременные повышения (III), длительные (1.5-3 мес.) понижения уровня воды (IV). Рассматривается зависимость проявления выделенных типов ГГСВ от параметров землетрясений (магнитуда, расстояние), величин удельной плотности энергии и максимальной скорости сейсмической волны, а также амплитудно-частотного состава движений грунта по записям на ближайшей сейсмостанции. На отдельных примерах рассмотрены гидрогеодинамические процессы формирования ГГСВ с использованием моделирования. Показано, что амплитудные вынужденные и свободные колебания уровня воды (типы I и II) могут возникать вследствие усиления вариаций давления подземных вод в системе “скважина-водовмещающая порода" при прохождении поверхностных сейсмических волн с периодами, соответствующими резонансной частоте скважины $(\tau=44.6 \mathrm{c})$; повышение уровня в течение десятков минут-часов (типы II и III) вызывается кратковременным ростом давления при нарушении стационарных условий течения воды в области непосредственно примыкающей к стволу скважины; местные сильные землетрясения, сопровождающиеся сотрясениями с интенсивностью $I_{\text {msk-64 }} \geq 5$ баллов, вызывают длительные понижения уровня воды (тип IV) вследствие падения давления с амплитудами до 0.1 бар в радиусе до первых сотен метров от скважины.
\end{abstract}

Ключевые слова: гидрогеосейсмические вариации, амплитудно-частотный состав движений грунта.

DOI: $10.31857 / \mathrm{S} 0002333720030035$

\section{ВВЕДЕНИЕ}

Распространение сейсмических волн при землетрясениях сопровождается различными нарушениями гидродинамического режима подземных и поверхностных вод - изменениями их разгрузок, давления и уровней воды [Wang, Manga, 2010]. При сильнейших землетрясениях с величинами магнитуды порядка 9, таких как на Аляске в 1964 г., Суматра-Андаманское 2004 г.; Япония, Тахоку 2011 г., эффекты сейсмических волн регистрировались на расстояниях до десятков тысяч км от эпицентра, отражая планетарный масштаб влияния таких землетрясений на гидродинамический режим гидросферы Земли.

Наблюдения за вариациями уровня воды в пьезометрических скважинах традиционно используются в системах геофизического монито- ринга и поиска предвестников землетрясений в сейсмоактивных регионах [Киссин, 1993; Копылова, 2006]. При проведении таких работ необходимо оценивать свойства наблюдательных скважин в качестве “датчиков” изменения напряженно-деформированного состояния геосреды при сейсмотектонических процессах, при барометрических, приливных и других природных и техногенных воздействиях [Копылова, 2009]. Кроме этого, регистрация разнообразных эффектов сейсмических волн в изменениях уровня воды в скважинах дает новые экспериментальные данные при решении актуальных научных задач по изучению вибрационного воздействия на состояние флюидонасыщенной среды сейсмоактивных регионов и гидрогеодинамических процессов в системе "скважина-водовмещающая порода". 
Эффекты вибрационного воздействия сейсмических волн, проявляющиеся в изменениях уровня воды, ниже называются гидрогеосейсмическими вариациями уровня воды, (ГГСВ). Различные виды ГГСВ отражают совокупные изменения давления подземных вод при динамической деформации водовмещающих пород и сопутствующих фильтрационных процессов, обусловленных изменением свойств водовмещающих пород, главным образом, их проницаемости [Копылова, Болдина, 2007; Wang, Manga, 2010]. В качестве механизмов изменения проницаемости рассматривались развитие в водовмещающих породах трещинной дилатансии [Bower, Heaton, 1978; Kanamori, Brodski, 2004; Копылова, Болдина, 2007], дегазация подземной воды [Roeloffs, 1998; Копылова и др., 2012], декольматация трешинно-порового пространства [Brodsky et al., 2003; Кочарян и др., 2011], эффекты кумулятивного накопления межблоковых деформаций [Кочарян и др., 2007].

Имеются многочисленные описания ГГСВ, например, в обобщающей работе [Wang, Manga, 2010]. В последние годы наибольшее число данных по ГГСВ получено в Китае, где функционирует наблюдательная сеть из более шестисот скважин [Sun, Liu, 2012; Shi et al., 2015; Sun et al., 2015]. На о. Тайвань во время землетрясения Чи-Чи, 1999 г., $M_{w}=7.5$, наблюдения проводились на сети из нескольких сотен скважин [Wang et al., 2001; Chia et al., 2008]. Наблюдения за вариациями уровня воды в отдельных скважинах проводились в США [Woodcook, Roeloffs, 1996; Roeloffs, 1998], в Японии [Matsumoto, Roeloffs, 2003], на Кавказе (Грузия) [Chelidze et al., 2019], в России на Восточно-Европейской платформе [Кочарян и др., 2011], на полуострове Камчатка [Копылова и др., 2016; Kopylova et al., 2017; Копылова, Болдина, 2019] и в других сейсмоактивных районах [Копылова и др., 2007]. Изучение особенностей проявления ГГСВ в отдельных скважинах дает возможность изучать гидрогеодинамические процессы в системе "скважина-водовмещающая порода", инициируемые воздействием сейсмических волн, а также прослеживать изменения в состоянии водонасыщенной среды во времени. Решение таких задач является необходимым условием эффективного геофизического мониторинга сейсмоактивных и асейсмичных территорий с использованием методов приповерхностной геофизики [Адушкин, Спивак, 2014].

Особый научный интерес имеют данные регистрации ГГСВ с частотой, соответствующей частоте регистрации смещений грунта сейсмометрическими приборами (Гц-десятки Гц). В таких случаях в вариациях уровня воды могут надежно выделяться отдельные фазы сейсмических волн, что дает новые возможности изучения гидрогеодинамических процессов в системе “скважина- водовмещающая порода" в высокочастотной области [Shalev et al., 2016a; b; Besedina et al., 2016].

Однако большая часть записей ГГСВ получена с периодичностью регистрации уровня воды от 1 до 10-15 мин [Roeloffs, 1998; The Monitoring ..., 2007; Kopylova et al., 2017; Chelidze et al., 2019]. Taкие записи ГГСВ являются информативными в отношении регистрации косейсмических компонент статического изменения напряженного состояния водовмещающих пород на эпицентральных расстояниях $d_{e}$ порядка 2-3 длин очагов землетрясений $D$ [Wakita, 1975; Копылова, 2006; Копылова и др., 2010]. Проявления ГГСВ в таких случаях характеризуются сложным характером, когда косейсмические скачки уровня воды фиксируются непосредственно во время прохождения сейсмических волн и затем сменяются разнообразными постсейсмическими (постдинамическими см. работу [Кочарян и др., 2011]) вариациями уровня. В дальних зонах очагов землетрясений $\left(d_{e} / D \gg 3 D\right)$ преобладающим видом вариаций уровня воды являются колебания (осцилляции) [Cooper et al., 1965; Копылова, Болдина, 2007; и др.].

Примеры систематизации данных о ГГСВ по их форме, длительности и времени проявления по отношению к моментам образования разрыва в очаге и вступления сейсмических волн в районе наблюдательных скважин приводятся в работах [Копылова, 2006; Shi et al., 2015; Болдина, 2017]. Наиболее обоснованным фактическими данными является разделение ГГСВ на косейсмические эффекты, наблюдаемые во время воздействия сейсмических волн, и постсейсмические эффек$m ы$, развивающиеся некоторое время после окончания сейсмических сотрясений.

Среди косейсмических ГГСВ в работе [Shi et al., 2015] выделены три основных типа:

- скачки понижения или повышения уровня воды (abrupt или step-like changes) на эпицентральных расстояниях $d_{e}$ до первых сотен км как реакция давления подземных вод на статическую компоненту косейсмической деформации водовмещающих пород при сильных землетрясениях [Wakita, 1975; Копылова и др., 2010; 2012; Shi et al., 2013; 2015];

- колебания уровня воды (oscillations) вследствие динамической деформации водовмещающих пород и гармонических вариаций давления при вступлении объемных и поверхностных сейсмических волн [Cooper et al., 1965; Копылова, Болдина, 2007; Копылова и др., 2012; Shi et al., 2015].

- постепенное повышение или понижение уровня воды (gradual change, см. работу [Shi et al., 2015) или “постдинамический отклик" (см. работу [Кочарян и др., 2011]), отражающее вариации давления вследствие изменения водопроницаемых свойств водовмещающих пород; примеры разнообразных проявлений приводятся в работах 
[Копылова, 2001; Brodsky et al., 2003; Roeloffs et al., 2003; Копылова и др., 2012; 2016].

С использованием высокочастотного цифрового оборудования были обнаружены сложные формы косейсмических ГГСВ, в которых наблюдалось наложение скачков и колебаний [Weingarten, $\mathrm{Ge}, 2014]$, а также наложение колебаний и постепенных изменений уровня воды [Wang et al., 2001]. Это показывает, что упрощенные варианты типизации косейсмических ГГСВ не вполне применимы для их описания в отдельных наблюдательных скважинах и этот вопрос требует дальнейшего развития с использованием качественных данных высокочастотной регистрации уровня (давления) подземной воды.

В работе [Shi et al., 2015] с использованием данных наблюдений на скважинах в континентальном Китае во время сильнейших землетрясений 2007-2011 гг. с $M_{w}=7.9-9.0$ в районах о-ва Суматра, Японии и Китая было показано, что на эпицентральных расстояниях $d_{e} / D>1$ преобладающим типом косейсмических ГГСВ являются колебания уровня вод ( $40 \%$ скважин). На меньших эпицентральных расстояниях $\left(d_{e} / D<1\right)$ преобладающим типом ГГСВ являются скачки уровня воды ( 39\% скважин). Приведенные статистические оценки представляются не вполне убедительными, т.к. в исследовании использовались скважины, в которых регистрация уровня воды осуществлялась с периодичностью один раз в час. Кроме этого, примеры косейсмических вариаций уровня воды приводятся на временном интервале в одни сутки, на котором невозможно оценить соответствие выделяемых вариаций уровня воды и вступлений сейсмических волн. Как показано в работе [Копылова и др., 2010], для надежной диагностики косейсмических скачков и других кратковременных эффектов в изменениях уровня воды необходимо проводить его регистрацию с периодичностью не реже 10-15 мин. При большей периодичности измерений выделение косейсмических скачков практически невозможно из-за их зашумленности воздействием сейсмических волн, барометрическими, приливными и др. природными и техногенными процессами.

В работе [Shi et al., 2015] также отмечается, что в 22-43\% скважин не были зафиксированы какие-либо изменения уровня воды. Мы полагаем, что возможными причинами отсутствия ГГСВ также могли быть техническое несовершенство методов наблюдений на отдельных скважинах и недостаточная детальность анализа вариаций уровня воды в сопоставлении с моментами вступления сейсмических волн.

Среди постсейсмических вариаций уровня воды в работе [Shi et al., 2015] выделены два их вида: длительные изменения (sustained changes - coseismic changes lasting from several weeks to several months) и кратковременные изменения (transient changes - co-seismic changes lasting less than one week). Такое разделение постсейсмических ГГСВ представляется достаточно обоснованным фактическими данными, за исключением жесткого их ограничения указанными временными границами, которые могут различаться для отдельных скважин, в зависимости от их конструкции и фильтрационных свойств водовмещающих пород. Примеры длительных постсейсмических изменений уровня воды приводятся в работах [Roeloffs, 1998; Копылова, 2001; Болдина, Копылова, 2017; Zhang et al., 2018]; кратковременные постсейсмические изменения уровня воды представлены в работах [Копылова и др., 2016; Болдина, Копылова, 2017; Kopylova et al., 2017].

Отметим также, что проявления ГГСВ различаются в скважинах, вскрывающих рыхлые осадочные породы с поровой проницаемостью, и в скважинах, пробуренных в уплотненных скальных горных породах с преимущественно трещинным типом проницаемости. Многообразие откликов уровня воды в близкорасположенных скважинах, вскрывающих дисперсные несвязные породы на глубинах до десятков-сотен метров, объясняется различной степенью их уплотнения/разуплотнения и эффектами частичного или полного разжижения при динамической деформации [Wang, Manga, 2010]. В таких скважинах могут наблюдаться впечатляющие масштабы проявления ГГСВ с амплитудами колебаний уровня воды до десятков метров, с самоизливом воды и выбросами обломков горных пород [Chia et al., 2008]. При проявлениях ГГСВ в таких скважинах основную роль имеют локальные особенности строения толщи водовмещающих пород и величины пороговых значений ее динамической деформации. Обычно такие скважины контролируют подземные воды первого от поверхности водоносного горизонта и, в силу сильной деформируемости водовмещающих пород и зашумленности записей уровня воды факторами-помехами, имеют ограниченное использование в системе геофизического мониторинга. Более перспективными объектами при проведении геофизического мониторинга сейсмоактивных территорий являются скважины, вскрывающие уплотненные слаботрещиноватые водовмещающие породы. В таких скважинах в изменениях уровня воды регистрируются барометрический и земноприливный отклики, реакция на статическую косейсмическую деформацию при образовании разрывов в очагах местных землетрясений [Копылова, 2009; Копылова и др., 2012], а также гидрогеодинамические предвестники на стадиях подготовки сильных землетрясений [Копылова, Болдина, 2019].

В настоящей работе представлены данные о ГГСВ, зарегистрированные в изменениях уровня воды в 800-метровой скважине Ю3-5, Камчатка, 


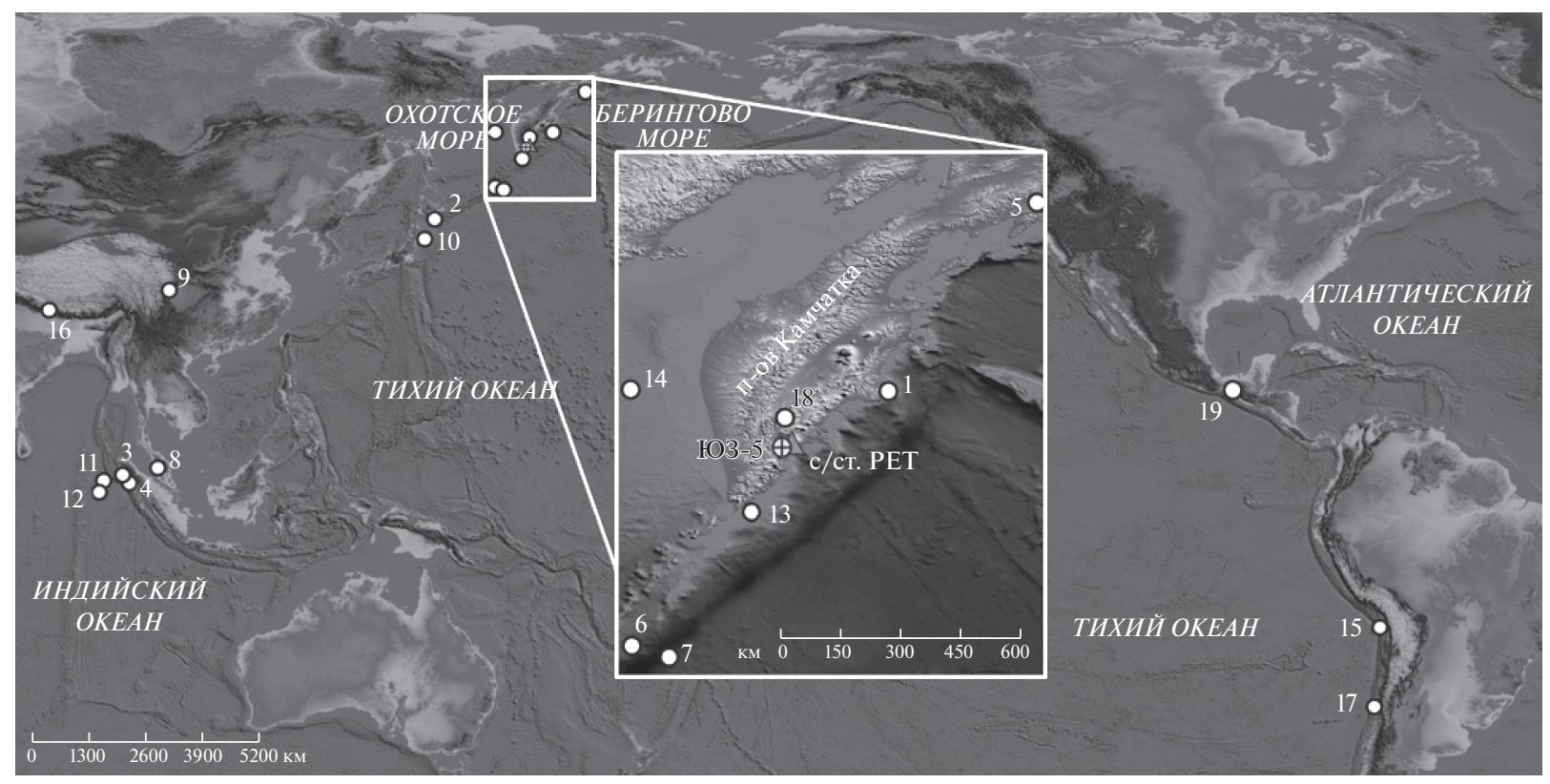

Рис. 1. Схема расположения эпицентров землетрясений (табл. 1), скважины Ю3-5 и сейсмостанции Петропавловск (с/ст. РЕТ) (на врезке).

с использованием цифрового оборудования. Наблюдения проводятся с 1997 г. в целях изучения гидрогеодинамических предвестников землетрясений и других эффектов сейсмичности в изменениях уровня воды [Копылова, 2006; Копылова и др., 2012; 2016; Kopylova et al., 2017; Копылова, Болдина, 2019]. В скважине Ю3-5 были зарегистрированы ГГСВ при 19-ти землетрясениях 1997-2017 гг. с $M_{w}=6.8-9.1$ на эпицентральных расстояниях $d_{\mathrm{e}}=$ $=80-14600$ км (рис. 1, табл. 1). С использованием этих данных представлена уточненная типизация ГГСВ; рассматривается зависимость проявления отдельных типов ГГСВ от параметров землетрясений и особенностей амплитудно-частотного состава максимальных фаз движений грунта по записям сейсмических волн, зарегистрированных на сейсмостанции Петропавловск (с/ст. РЕТ), находящейся на расстоянии около 20 км от скважины. Рассматриваются на отдельных примерах процессы формирования выделенных типов ГГСВ в системе “скважина-водовмещающая порода" с использованием моделирования.

\section{ИСХОДНЫЕ ДАННЫЕ И МЕТОДИКА ИССЛЕДОВАНИЯ}

Камчатский филиал Федерального исследовательского центра "Единая геофизическая служба Российской академии наук” (КФ ФИЦ ЕГС РАН) проводит многолетние наблюдения за вариациями уровня воды в скважине Ю3-5 с использованием аппаратурных комплексов Кедр А2 (19972004 гг., интервал измерений 10 мин) и Кедр ДМ
(2005-2017 гг., интервал измерений 5 мин), оборудованных высокочувствительным ультразвуковым датчиком уровня воды. Производитель оборудования - ООО Полином, г. Хабаровск. Описание уровнемерного оборудования приводится в работах [Копылова, Болдина и др., 2016; Kopylova, Boldina et al., 2017]. В течение всего времени наблюдений обеспечивалась чувствительность измерений уровня воды $-0.1 \mathrm{~cm}$, атмосферного давления -0.1 гПа.

Данные о скважине Ю3-5 приводятся в работах [Копылова, 2006; Копылова, Болдина и др., 2016; Kopylova, Boldina et al., 2017; Болдина, Копылова, 2017]. Координаты скважины 53.169 с.ш., $158.414^{\circ}$ в.д., глубина 800 м. В диапазоне глубин 0-310 м ствол скважины обсажен металлической трубой. На глубинах 310-800 м ствол скважины открыт и связан с водовмещающими породами, представленными алевролитами и сланцами позднемелового возраста. Их водопроводимость $T=7.8 \mathrm{~m}^{2} /$ сут оценивалась по данным откачки [Копылова, Болдина, 2007]. Минерализация подземной воды 0.25 г/л. Уровень воды находится на глубине 1-1.5 м ниже поверхности земли.

В фоновых изменениях уровня воды проявляются внутригодовые сезонные вариации с амплитудой до 50 см, а также барометрические и приливные вариации [Копылова, 2006; 2009; Болдина, Копылова, 2017]. По результатам кросс-спектрального анализа часовых записей уровня воды и атмосферного давления барометрическая эффективность вариаций уровня воды в диапазоне периодов от 6 ч до первых десятков суток состав- 


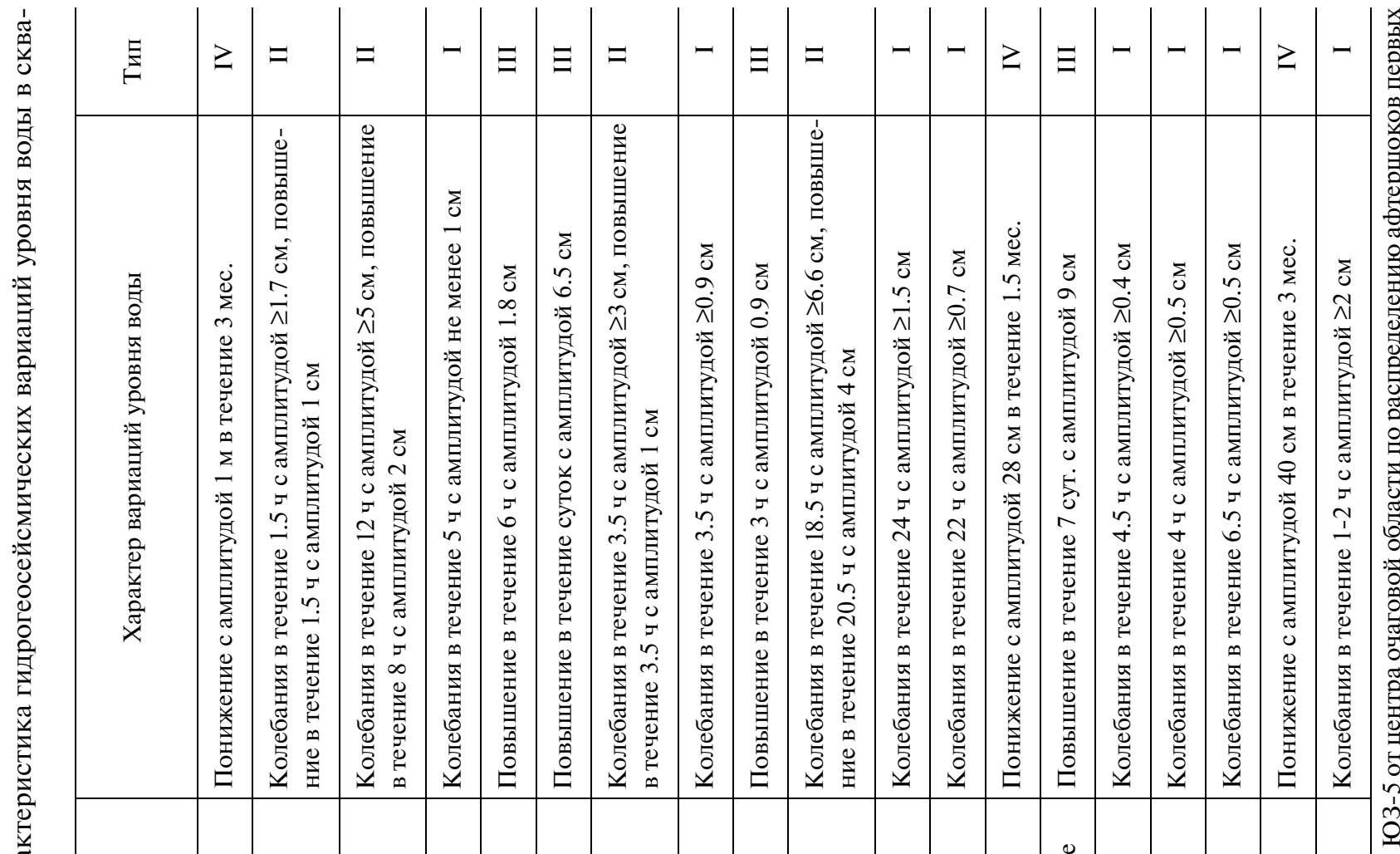

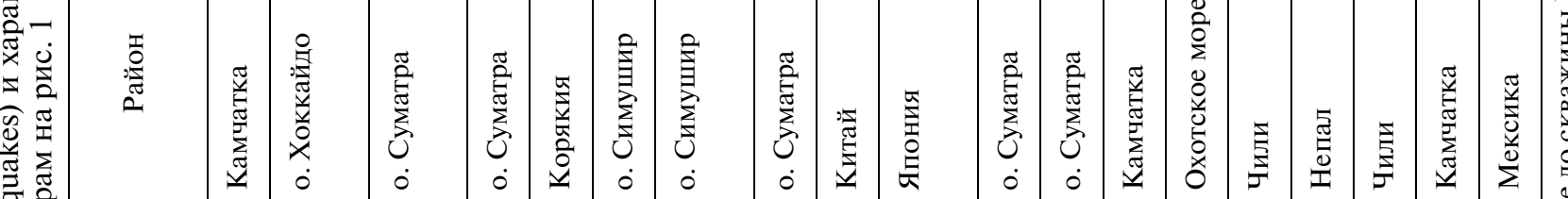

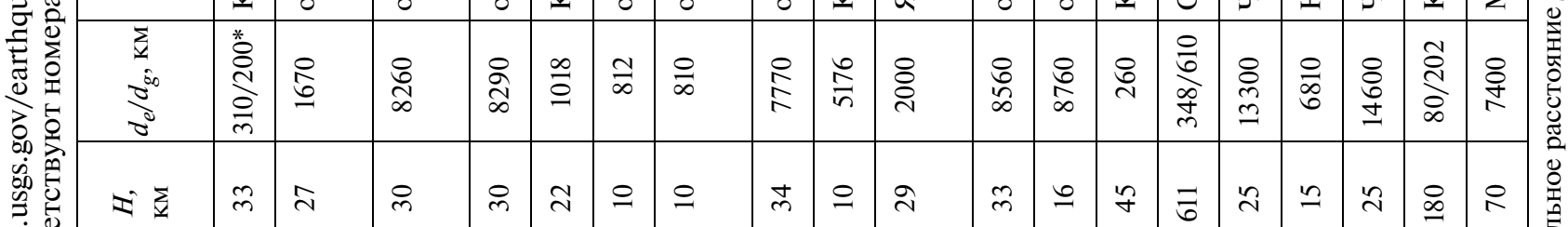

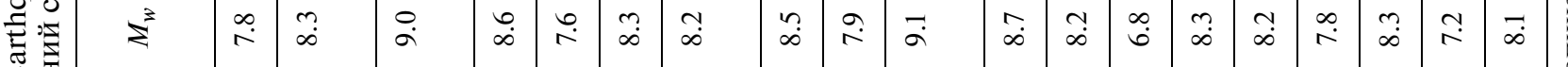

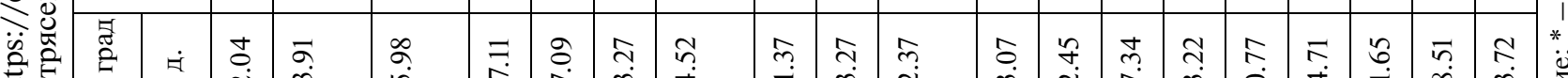

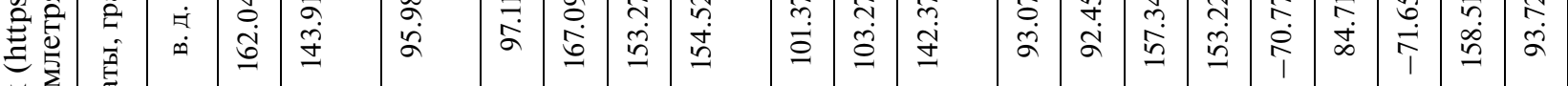

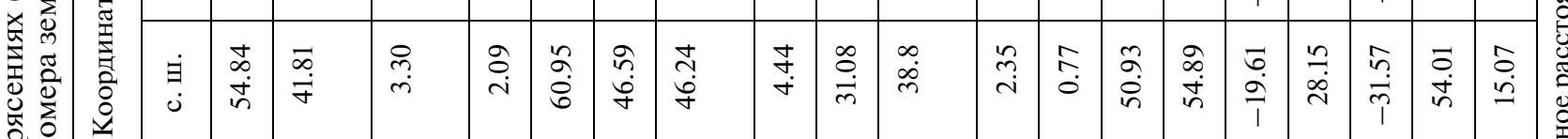

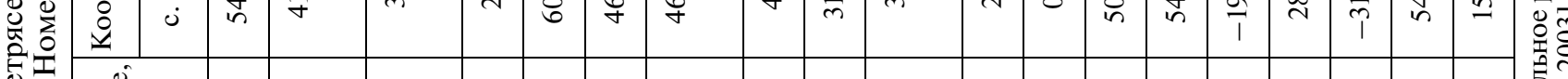

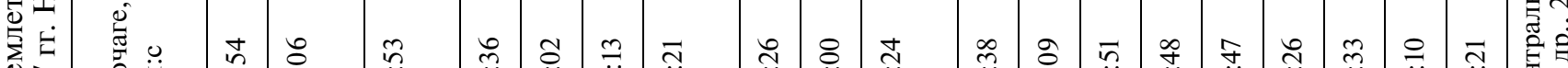

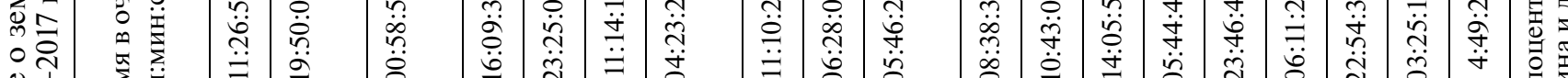

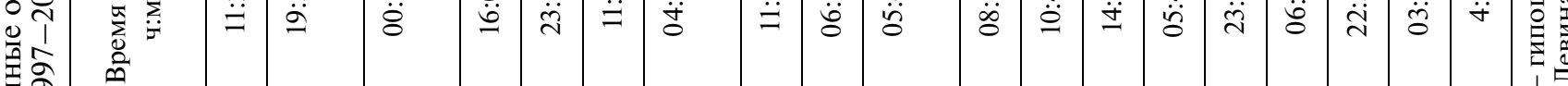

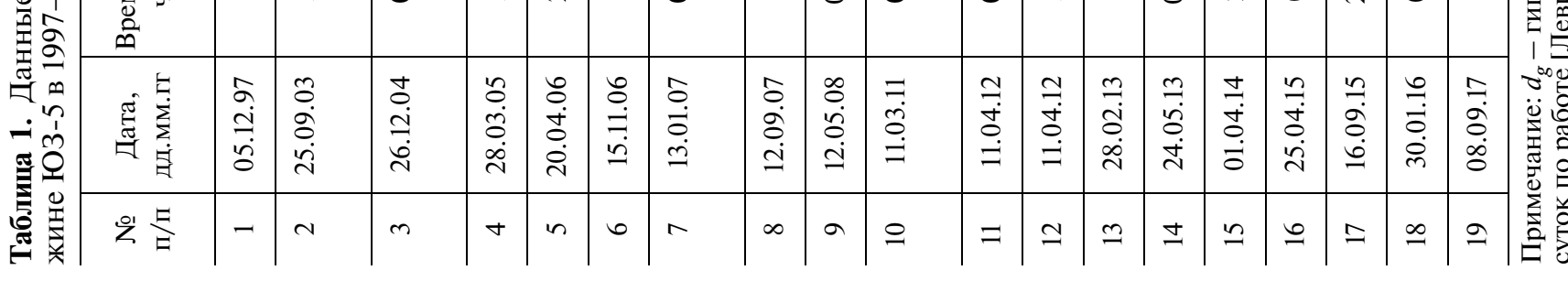


ляет $0.4 \mathrm{~cm} / г$ Па; на периодах от 2 до 6 ч барометрическая эффективность монотонно возрастает

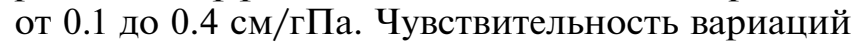
уровня по отношению к объемной деформации водовмещающих пород в диапазоне суточной и полусуточной групп приливных волн составляет $0.161 \mathrm{~cm} / 10^{-9}$. Данные о строении скважины, упругих и фильтрационных свойствах водовмещающих пород, закономерностях гидрогеодинамического режима и описания ГГСВ при сильных местных и удаленных землетрясениях представлены в предыдущих публикациях [Копылова, 2006; 2009; Копылова, Болдина, 2006; Копылова и др., 2010 Болдина, Копылова, 2013; 2016; 2017; Болдина, 2017] и на сайте КФ ФИЦ ЕГС РАН: http://www.emsd.ru/lgi/places/uz5.

Среди совокупности зарегистрированных ГГСВ (рис. 1, табл. 1) выделены по морфологическим особенностям (по форме) и по продолжительности четыре типа (табл. 1, рис. 2-рис. 5) [Копылова и др., 2017]:

- тип I - вынужденные и свободные колебания в течение времени от часов до одних суток (рис. 2);

- тип II - колебания с наложением кратковременных, от минут-часов до суток, остаточных повышений (рис. 3);

- тип III - кратковременные остаточные повышения в течение времени от часов до одних суток (рис. 4);

- тип IV - длительные (1.5-3 мес.) понижения уровня воды (рис. 5).

На рис. 2-рис. 5 ГГСВ приводятся в сопоставлении с записью сейсмических волн на сейсмостанции Петропавловск (с/ст. РЕТ, координаты $53.024^{\circ}$ с.ш., $158.653^{\circ}$ в.д.), зарегистрированных датчиком STS-1 на канале BHZ с частотой 20 Гц.

Принятый интервал регистрации уровня воды в 5-10 мин позволяет уверенно выделять ГГСВ III и IV типов и оценивать их параметры - амплитуды и продолжительности. Вместе с тем, такая периодичность регистрации уровня не обеспечивает достоверные оценки амплитуд и продолжительностей ГГСВ I и II типов, характерной особенностью которых являются вынужденные колебания уровня воды непосредственно во время вступления сейсмических волн и свободные затухающие колебания после прохождения сейсмических волн. По 10 и 5-минутным записям ГГСВ I и II типов можно лишь констатировать факт наличия таких вариаций по увеличению амплитуды изменений уровня и присутствию характерных "пиков" (рис. 2, рис. 3). Поэтому при характеристике ГГСВ I и II типов (табл. 1) приводятся величины максимальных зарегистрированных амплитуд (со знаком “"”), которые, вероятнее всего, меньше их реальных значений.
В сентябре 2017 г. на скважине, в дополнение к оборудованию Кедр ДМ, была установлена аппаратура в составе датчика PAA 36XW Keller, Швейцария и регистратора CR-6 Cambell, CША для регистрации вариаций давления на глубине 5.6 м с частотой 10 Гц. Результаты сопоставления данных за сентябрь-декабрь 2017 г., полученных двумя комплектами аппаратуры, подтверждают их идентичность в части определения характера сезонного тренда и параметров барометрического и приливного откликов уровня воды.

09.09.2017 г. в районе Мексики произошло землетрясение с $M_{w}=8.2$ (№ 19 в табл. 1 и на рис. 1). Это землетрясение сопровождалось изменениями уровня (давления) воды, зарегистрированными обоими комплектами оборудования. На рис. 6 приводятся данные 5-минутной регистрации уровня воды во время прохождения сейсмических волн от этого землетрясения, полученные Кедр ДМ, совместно с записями давления с частотой 10 Гц и смещениями поверхности земли на канале BHZ на с/ст. PET.

В 10-герцовых записях давления подземной воды четко выделяются вступления $S$ - и $L$-волн, идентичные сейсмической записи. Продолжительность колебаний давления составляла не менее 1.5 ч при максимальной амплитуде 3 гПа, что эквивалентно 3 см водяного столба. По данным 5-минутных измерений уровня воды также диагностируется наличие ГГСВ $I$ типа продолжительностью не менее одного часа с максимальной зарегистрированной амплитудой колебаний уровня в 2 см, что в 1.5 раза меньше, по сравнению с зарегистрированными вариациями давления подземной воды.

Приведенный пример демонстрирует возможность выделения по данным 5-минутной регистрации уровня воды ГГСВ I и II типов и получать приблизительные оценки их амплитуд, продолжительности и характера вариаций (табл. 1).

\section{ОЦЕНКА ИНТЕНСИВНОСТИ ВОЗДЕЙСТВИЯ СЕЙСМИЧЕСКИХ ВОЛН В РАЙОНЕ СКВАЖИНЫ}

В работе [Wang, Manga, 2010] для оценки сейсмического воздействия на природные флюидодинамические системы применялась величина удельной плотности энергии в сейсмической волне $e$, Дж/м ${ }^{3}$ :

$$
\lg d_{e}=0.48 M_{w}-0.33 \lg e-1.4,
$$

где $d_{e}$ - эпицентральное расстояние, км; $M_{w}$ магнитуда землетрясения. В табл. 2 приводятся величины $e$ в районе скважины Ю3-5, рассчитанные по (1).

В качестве параметра интенсивности сейсмического воздействия также рассматривалась мак- 
№ 4

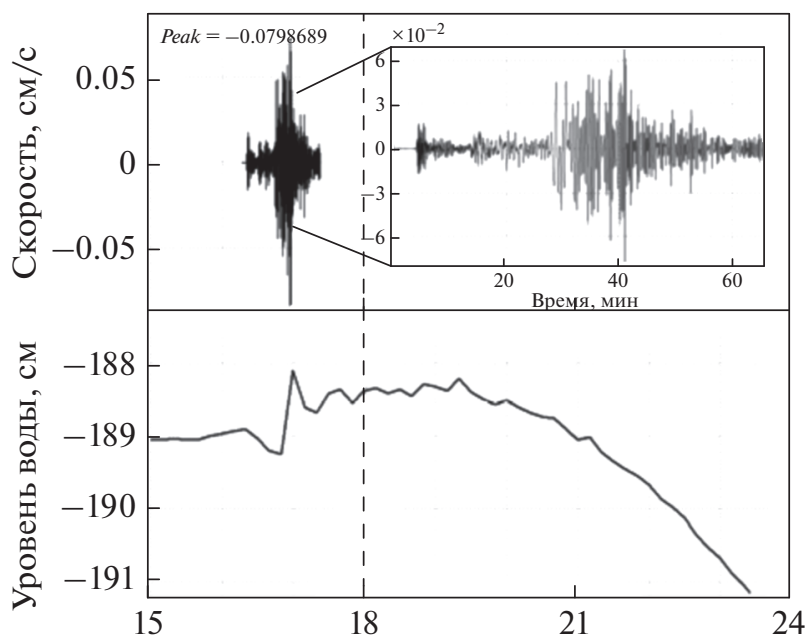

$\times 10^{-2}$
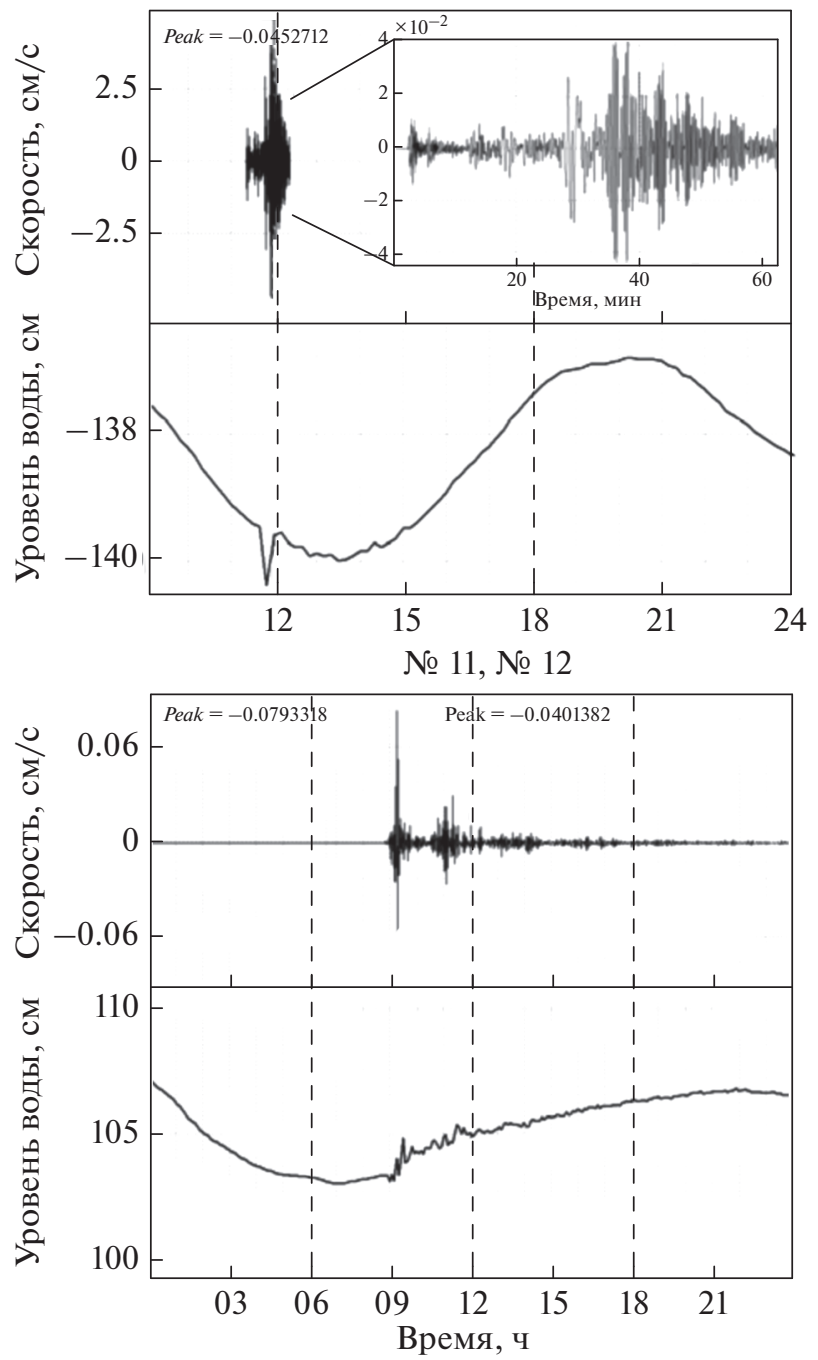

Тип I

№ 15
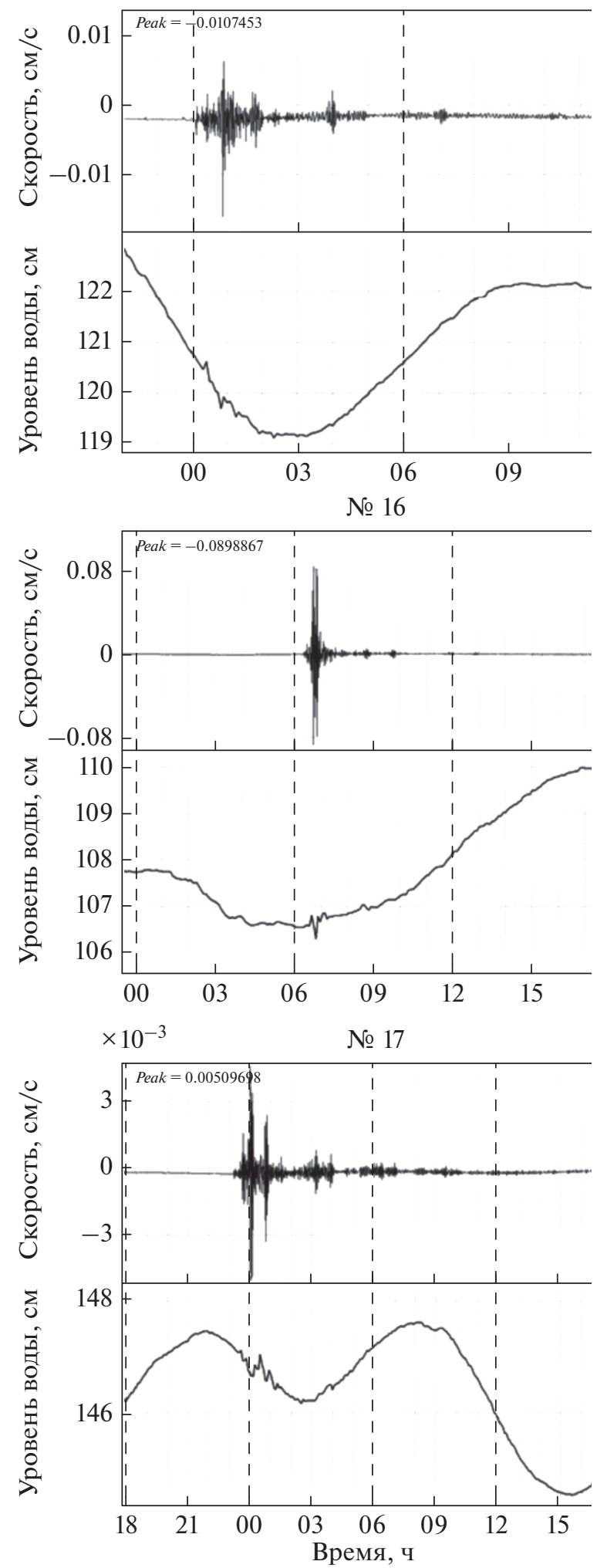

Рис. 2. Гидрогеосейсмические вариации уровня воды в скважине Ю3-5 (тип I), в сопоставлении с записями землетрясений на канале BHZ, с/ст. РЕT. Номера землетрясений соответствуют табл. 1 и рис. 1. 


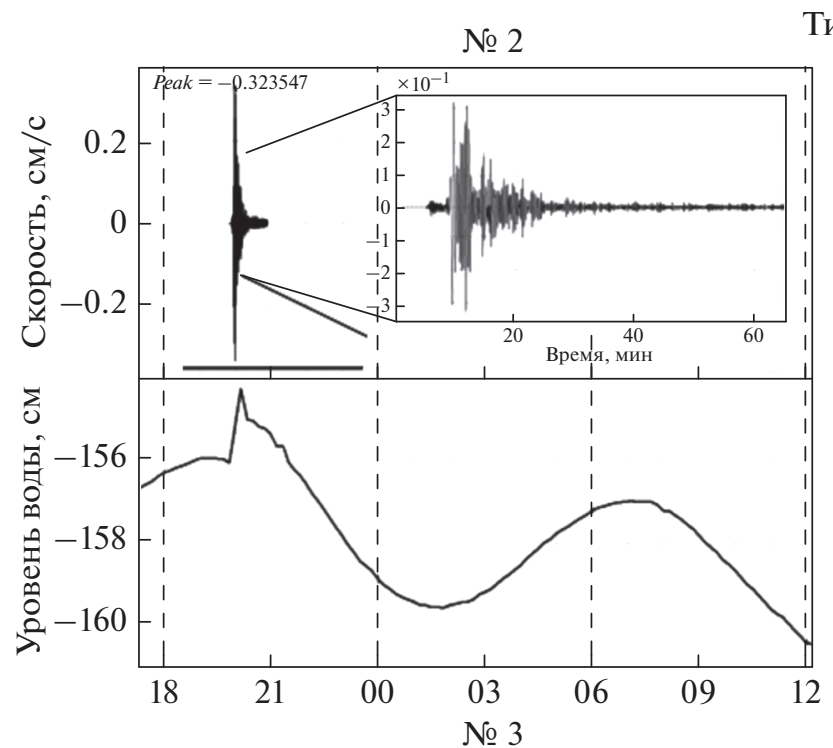

Тип II
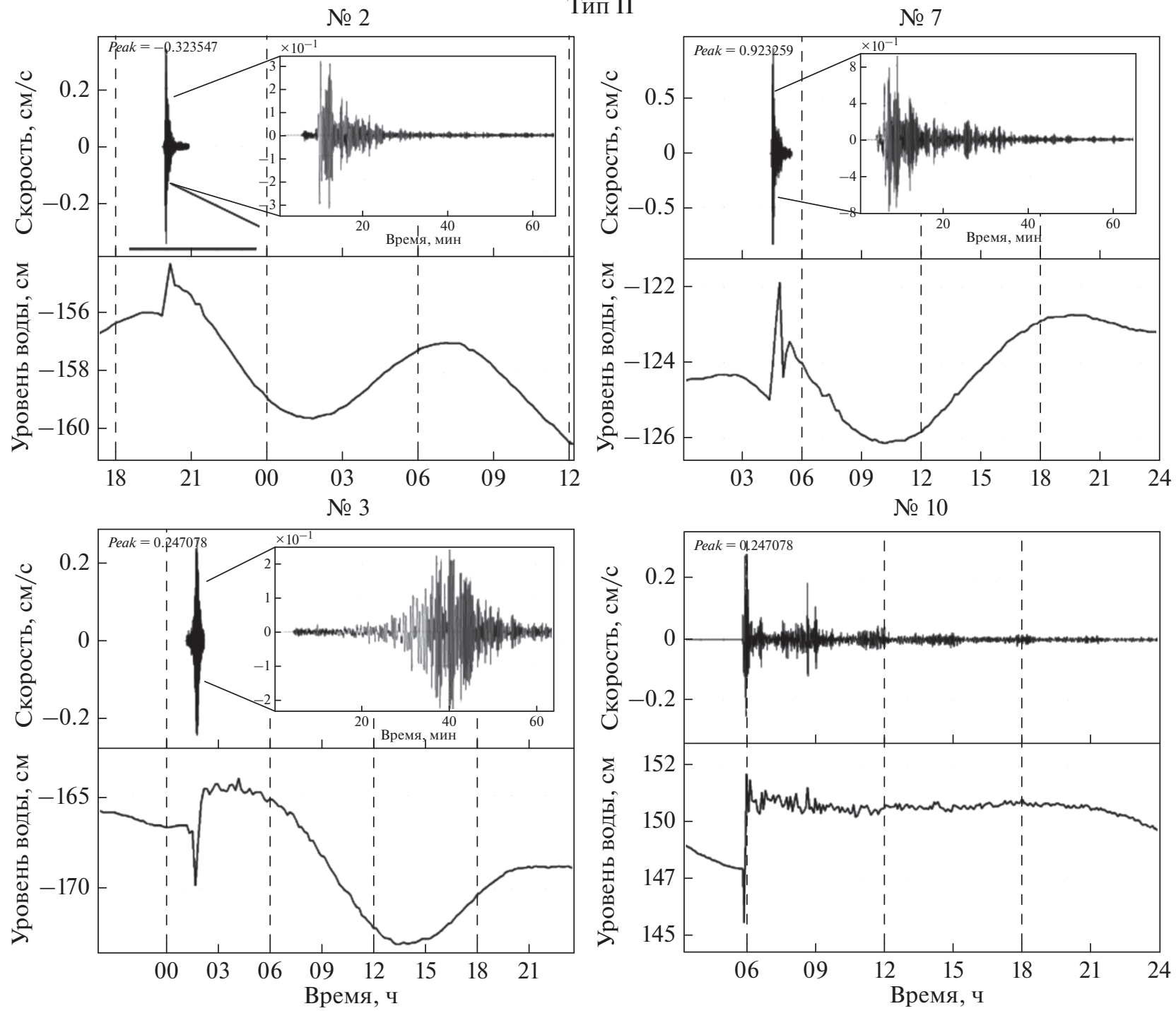

Рис. 3. Гидрогеосейсмические вариации уровня воды в скважине Ю3-5 (тип II), в сопоставлении с записями землетрясений на канале BHZ, с/ст. PЕT. Номера землетрясений соответствуют табл. 1 и рис. 1.

симальная скорость смешения грунта $V_{m}$, см/с в районе скважины при землетрясениях (табл. 1). Для ее оценки использовались зависимости, приведенные в работе [Gomberg et al., 2006]:

$$
\begin{gathered}
V_{m}=81 /\left(0.9+d_{e} / D\right)^{2}, \\
V_{m}=21 /\left(d_{e} / D\right)^{1.5},
\end{gathered}
$$

где $D-$ максимальный линейный размер очага землетрясения в км, рассчитанный по формуле из работы [Ризниченко, 1976]:

$$
\lg D=0.44 M_{w}-1.289 \text {. }
$$

Результаты расчетов средней величины $V_{m}$ по (2)-(3) представлены в табл. 2.

На рис. 7 показано распределение четырех типов ГГСВ в зависимости от соотношения вели- чин $M_{w}, d_{e}$ и $е$ (см. рис. 7a), $M_{w}, d_{e}$ и $V_{m}$ (см. рис. 7б). Из полученных распределений следует, что с ростом интенсивности сейсмического воздействия на рассматриваемую систему "скважина-водовмещающая порода” происходит закономерное изменение ее реакции на прохождение сейсмических волн, и с увеличением значений $e$ и $V_{m}$ происходит смена типов ГГСВ от I к IV.

Кроме этого, были использованы записи всех 19-ти землетрясений на с/ст. РЕТ, зарегистрированные трехкомпонентным широкополосным датчиком STS-1. По записям, с использованием их эмуляции и фильтрации в различных частотных диапазонах в программе DIMAS [Дрознин, Дрознина, 2010], проводились оценки максимальных скоростей (табл. 2), а также ускорений и 
Тип III
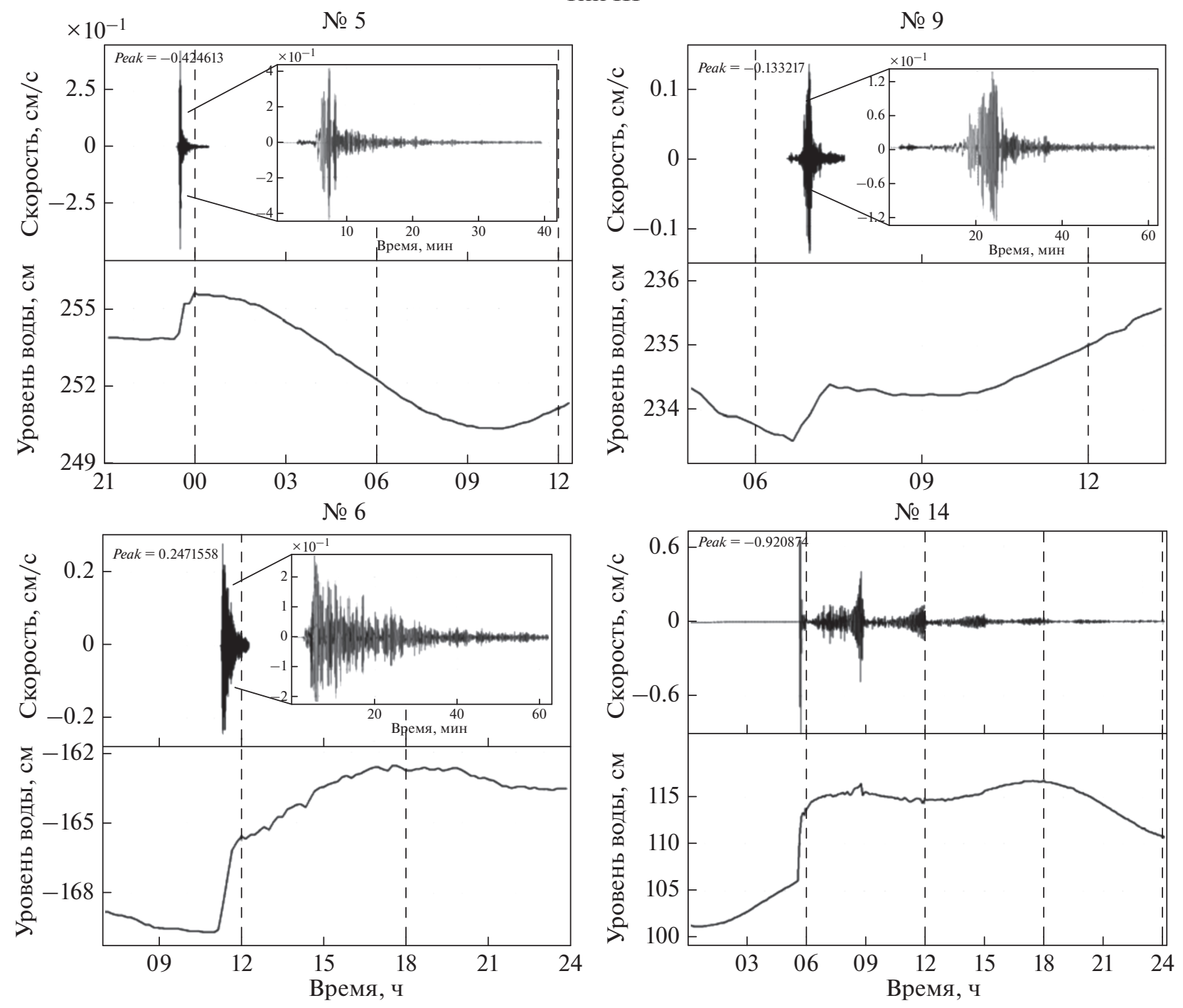

Рис. 4. Гидрогеосейсмические вариации уровня воды в скважине ЮЗ-5 (тип III), в сопоставлении с записями землетрясений на канале BHZ, с/ст. PET. Номера землетрясений соответствуют табл. 1 и рис. 1.

смещений поверхности Земли на каналах BHN, BHE, BHZ при прохождении сейсмических волн.

Для записей землетрясений, сопровождающихся ГГСВ I-III типов (табл. 1, табл. 2), характерны интенсивные проявления поверхностных волн (рис. 2-рис. 4). При таких землетрясениях оценки максимальных скоростей смещения грунта проводились с помощью полосовой фильтрации с набором фильтров $F=10$ в диапазоне частот от 0.01 до 0.1 Гц. На рис. 8 представлен пример полосовой фильтрации записи скорости смещений грунта на канале BHN при землетрясении 26.12.2004 г. (№ 3 на рис. 1, табл. 1, табл. 2). При этом землетрясении максимальная скорость смещения грунта на канале BHN составляла $0.316 \mathrm{~cm} / \mathrm{c}$ (рис. 8, левая диаграмма) и соответствовала центральной частоте 0.04 Гц (рис. 8, правая диаграмма).
В записях местных землетрясений, сопровождавшихся ГГСВ IV типа (№№ 1, 13 и 18 на рис. 1 и в табл. 1), поверхностные волны не проявлялись (рис. 5). Для таких событий оценки максимальных скоростей смещения грунта проводились по объемным волнам $S$ с помощью полосовой фильтрации в диапазоне частот от 0.01 до 0.3 Гц с набором фильтров от $F=10$ и до $F=15$ для более точного определения центральной частоты.

В результате такой обработки сейсмических записей для каждого из 19-ти землетрясений были получены оценки величин максимальных скоростей движений грунта по трем каналам и центральных частот их проявления (табл. 2). На рис. 9 представлены распределения ГГСВ типов I-IV в зависимости от параметров амплитудно-частотного состава максимальных фаз скорости движе- 


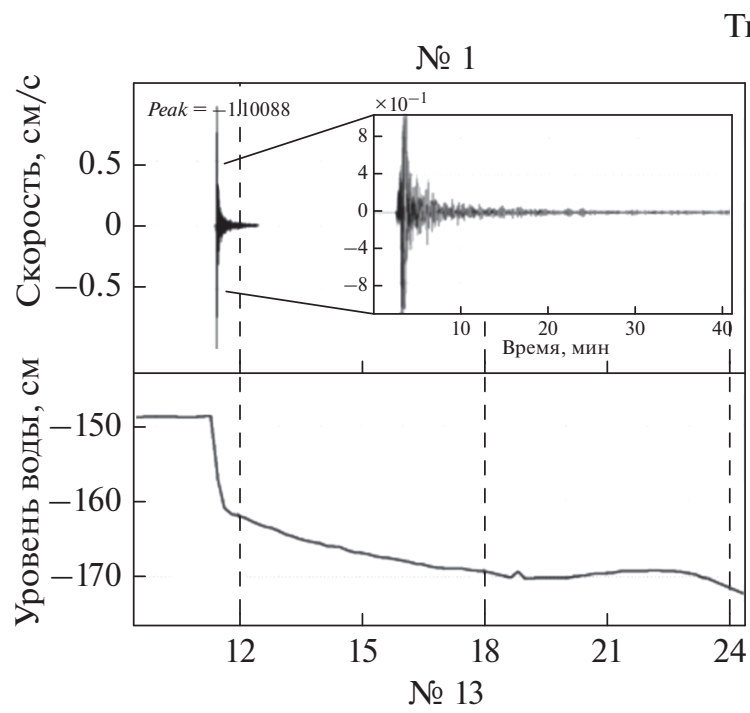

Тип IV
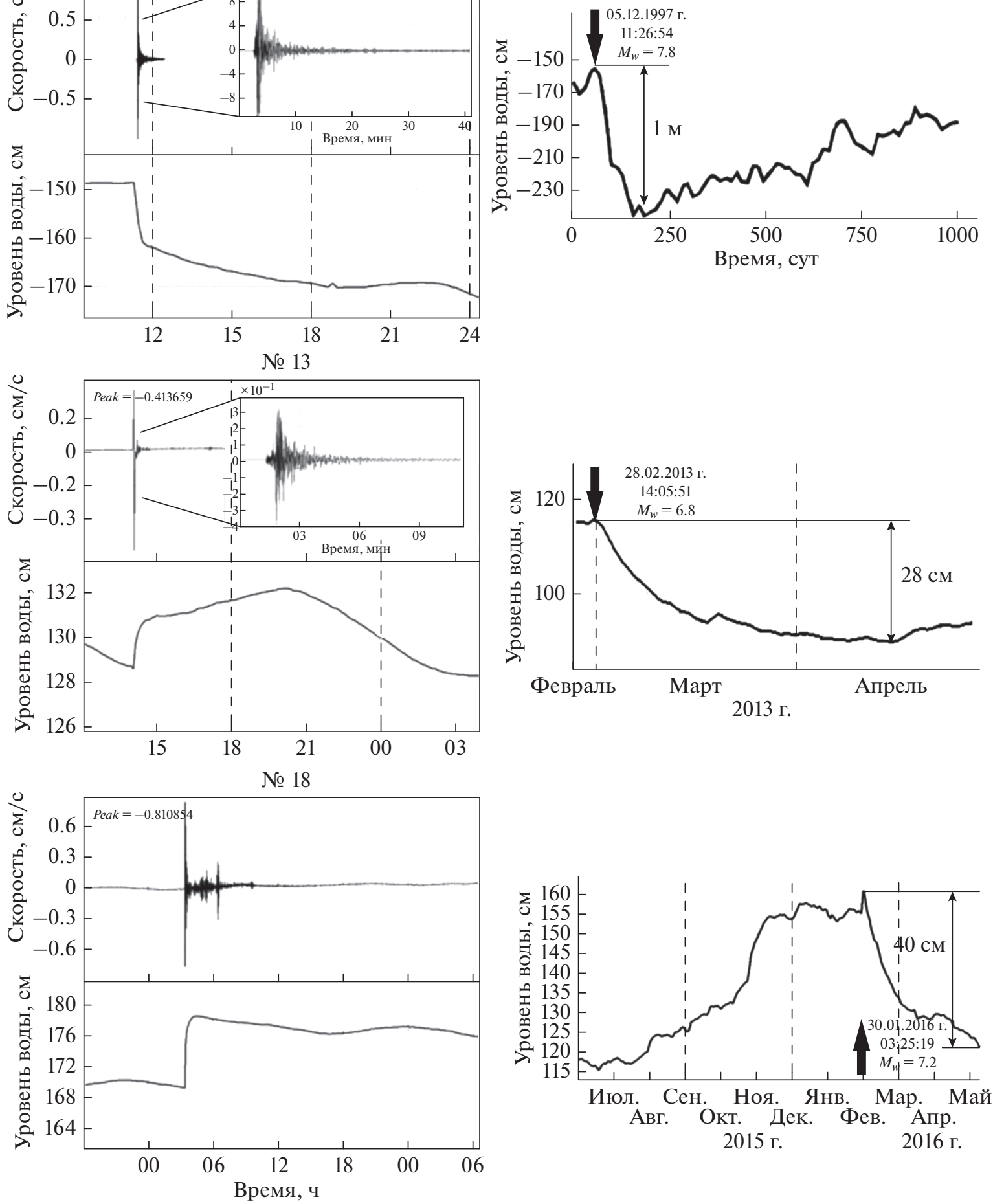

Рис. 5. Гидрогеосейсмические вариации уровня воды в скважине Ю3-5 (тип IV), в сопоставлении с записями землетрясений на канале BHZ, с/ст. PЕT. Номера землетрясений соответствуют табл. 1 и рис. 1.

ния грунта на сейсмостанции РЕТ на трех каналах. Положение кружков ГГСВ типов I-IV по горизонтальной оси соответствует центральным частотам полос фильтрации сейсмической записи, в которых были зафиксированы максимальные скорости движения грунта (табл. 2). 


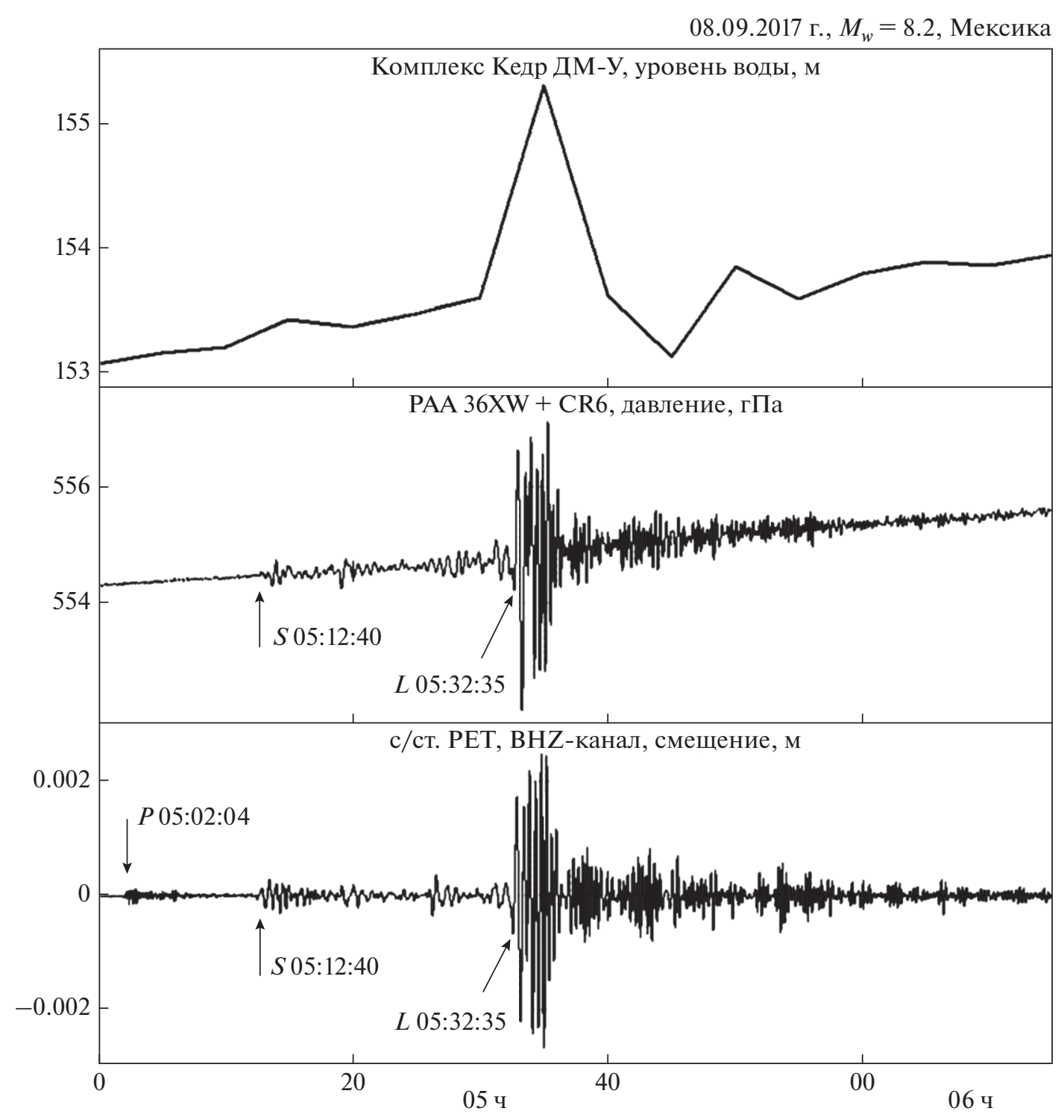

Рис. 6. Вариации уровня воды с периодичностью измерений 5 мин (Кедр ДМ) и давления подземных вод на глубине 5.6 м с частотой регистрации 10 Гц (датчик РАA 36XW) в скважине Ю3-5 при землетрясении 09.09.2017 Г., $M_{w}=8.2$, Мексика (№ 19 в табл. 1) в сопоставлении с записью смещений на канале BHZ, с/ст. РЕT.

Характер распределения I-IV типов ГГСВ (рис. 9) показывает очевидную связь между проявлениями их отдельных типов в зависимости от амплитудно-частотного состава максимальных фаз движений грунта на ближайшей сейсмостанции. При этом низкочастотные и низкоамплитудные сейсмические сигналы при прохождении поверхностных волн сопровождаются колебаниями уровня воды (тип I ГГСВ). При увеличении амплитуды сейсмического сигнала на колебательный режим могут накладываться кратковременные повышения уровня (тип II ГГСВ). Относительно высокочастотные сигналы поверхностных волн сопровождаются кратковременными повышениями уровня воды (тип ІІІ ГГСВ). При увеличении амплитуды сигнала по данным регистрации объемных волн, в случаях наиболее сильных местных землетрясений, сопровождающихся ощутимыми сотрясениями интенсивностью $I_{\text {msk-64 }}$ не менее 5-6 баллов, проявляются длительные (месяцы) понижения уровня воды (тип IV ГГСВ).

\section{ПРОЦЕССЫ ФОРМИРОВАНИЯ ГГСВ I-IV ТИПОВ}

Исследование процессов формирования ГГСВ I-IV типов в скважине Ю3-5 проводилось путем сопоставления наблюденных вариаций уровня воды с его расчетным поведением по математическим моделям [Cooper et al., 1965; Roeloffs, 1998; 


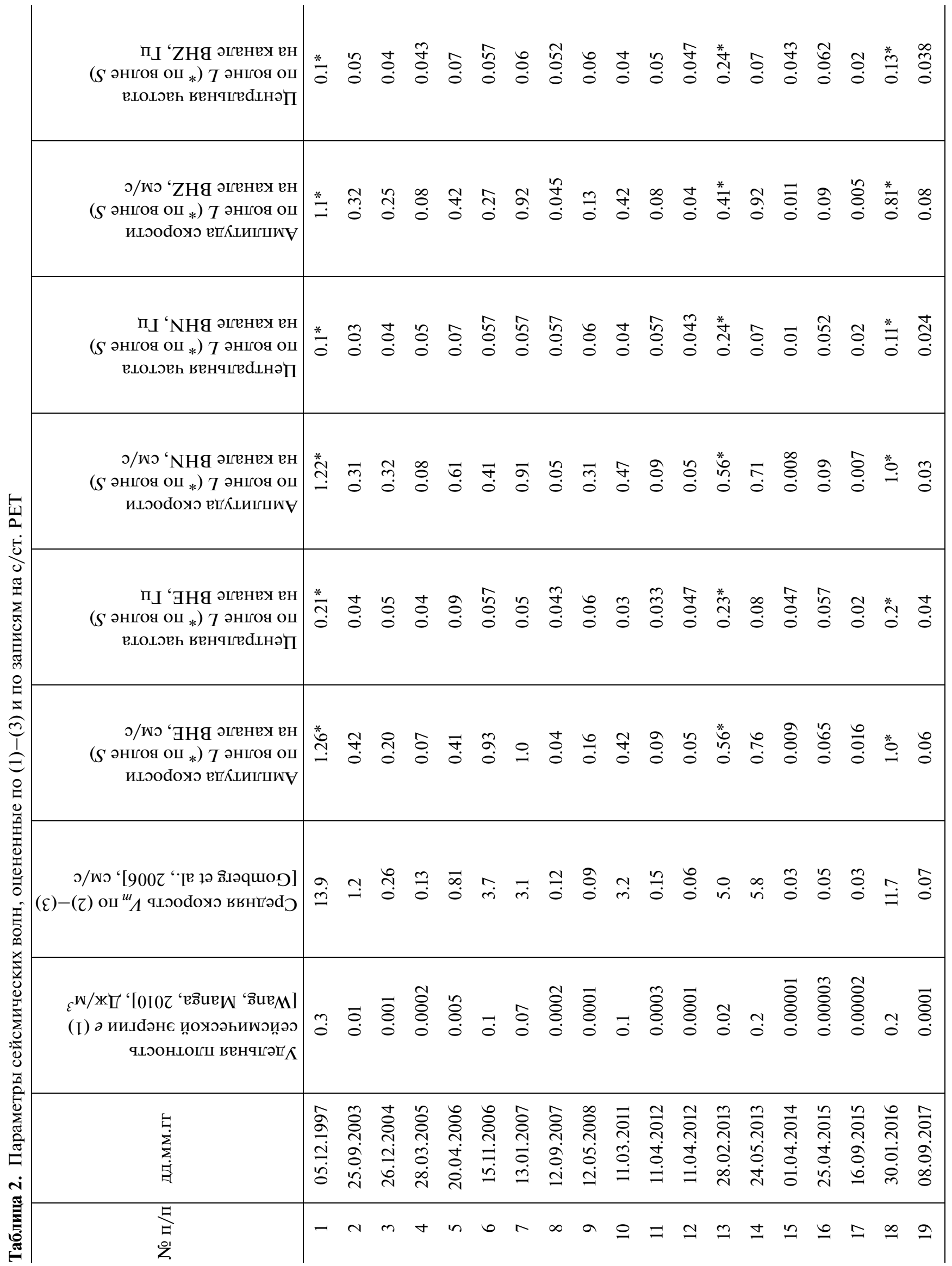



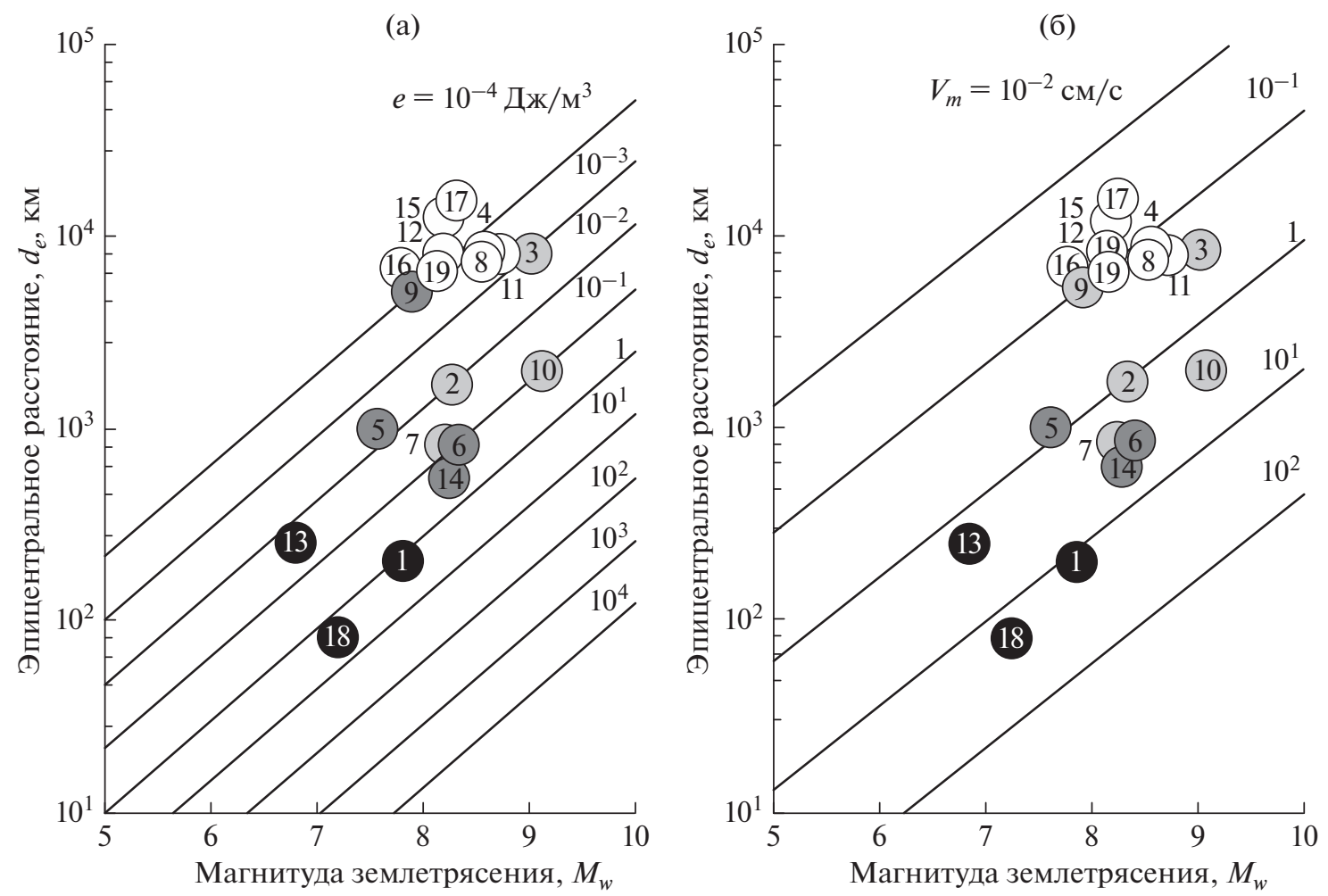

Рис. 7. Распределение выделенных типов ГГСВ в скважине Ю3-5 (тип I - белые кружки, тип II - серые, тип III - темно-серые, тип IV - черные) в зависимости от параметров землетрясений $M_{w}$ и $d_{e}$, величины плотности сейсмической энергии в волне $e$ (а) и величины ее максимальной скорости $V_{m}$ (б). Цифры - номера землетрясений по табл. 1 , табл. 2 и рис. 1 , рис. 2 -рис. 5.

Brodsky et al., 2003] с учетом параметров водовмещающих пород и геометрических размеров скважины. Такой подход позволяет получать количественные критерии условий возникновения и развития различных гидрогеодинамических процессов при воздействии сейсмических волн и строить феноменологические модели формирования ГГСВ для реальной наблюдательной скважины [Болдина, Копылова, 2010; 2013; Болдина, 2017].

В работе [Cooper et al., 1965] показано, что колебания уровня воды в скважине (ГГСВ I и II типов (рис. 2 и рис. 3)) обусловлены двумя факторами - гармоническими вариациями давления подземных вод при динамической деформации водовмещающих пород и вертикальными перемещениями поверхности земли и ствола скважины. При этом степень реакции уровня воды на прохождение сейсмических волн определяется геометрическими характеристиками скважины, величинами коэффициента водопроводимости и упругой емкости водовмещающих пород, а также зависит от вида и периода сейсмических волн.

Для описания колебаний уровня воды в скважине Ю3-5 использовалось аналитическое выражение для амплитудного соотношения между вариациями уровня воды $x_{0}$ и напором $h_{0}$ с учетом резонансного эффекта усиления вариаций давления подземной воды в системе “скважина-водовмещающая порода” при прохождении поверхностных сейсмических волн [Cooper et al., 1965; Копылова, Болдина, 2007; Болдина 2017]:

$$
\begin{aligned}
A=x_{0} / h_{0} & =\left[\left(1-\frac{\pi r_{w}^{2}}{T \tau} \operatorname{Kei\alpha }_{w}-\frac{4 \pi^{2} H_{e}}{\tau^{2} g}\right)^{2}+\right. \\
& \left.+\left(\frac{\pi r_{w}^{2}}{T \tau} \operatorname{Ker}_{w}\right)^{2}\right]^{-1 / 2},
\end{aligned}
$$

где: $H_{e}-$ эффективная высота столба воды в скважине, равная $H_{e}=H+3 d / 8$ (где $H$ - высота столба воды в обсаженном стволе скважины; $d-$ высота столба воды в области вскрытия водовмещающих пород); $\tau$ - период сейсмической волны, $\alpha_{w}=r_{w}(\omega S / T)^{1 / 2}-$ безразмерная функция частоты, выраженная через параметры водовмещающих пород и геометрические размеры скважины ( $T$ - коэффициент водопроводимости, $S$ - упругая емкость водовмещающих пород, $r_{w}-$ радиус скважины в области ее связи с водовмещающими породами, $\omega-$ угловая частота сейсмической волны); Ker $\alpha_{w}, K_{e i \alpha_{w}}$ - действительная и мнимая части функции Кельвина нулевого порядка. 

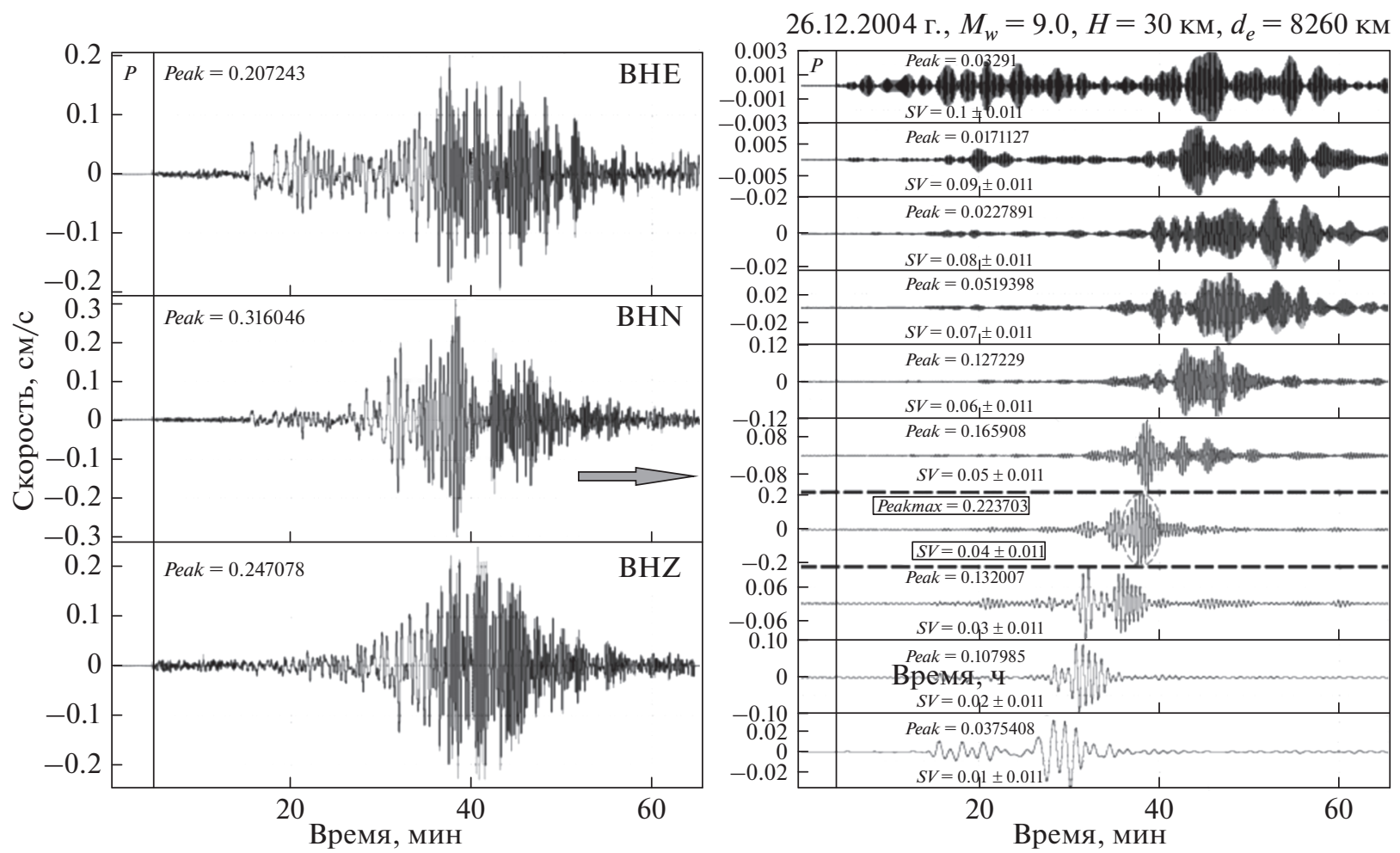

Рис. 8. Записи землетрясения 26.12.2004 г. (№ 3 в табл. 1, 2) на каналах ВНЕ, ВНN и ВНZ, с/ст. РЕТ с максимальными амплитудами Peak (левая диаграмма) и полосовая фильтрация записи скорости смещений грунта на канале BHN в программе DIMAS (правая диаграмма). Жирной пунктирной линией выделено ограничение частотной полосы SV= $=0.04 \pm 0.011$ Гц, в которой зафиксирована максимальная амплитуда скорости движений грунта Peakmax $=0.2237 \mathrm{~cm} / \mathrm{c}$ (выделена эллипсом).

На рис. 10 на примере Суматра-Андаманского землетрясения 26.12.2004 г., $M_{w}=9.1$ (№ 3 табл. 1, рис. 3) рассматривается возникновение колебаний уровня воды в скважине Ю3-5, существенно превышающих вертикальное смещение поверхности земли $\left(x_{0} / h_{0}>1\right)$. Этот пример показывает, что усиление колебаний давления подземных вод в скважине возникает при прохождении поверхностных сейсмических волн с периодом $\tau=44.6 \mathrm{c}$ при величине параметра $T / r_{w}^{2} \geq 1 \mathrm{c}^{-1}$ [Копылова, Болдина, 2007]. В указанной работе приведены величины параметров для скважины Ю3-5: $T=$ $=0.9 \times 10^{-4} \mathrm{M}^{2} / \mathrm{c}, S=18.7 \times 10^{-5} \mathrm{M}^{-1}, r_{w}=0.084 \mathrm{M}$, а также величина эффективной высоты столба воды в скважине $H_{e}=494$ м, при которых проявляется резонансный эффект усиления вариаций давления подземной воды в стволе скважины.

Кратковременные повышения уровня воды после вступления сейсмических волн (тип III ГГСВ, рис. 4) отражают импульсный рост давления подземных вод при возникновении эффекта нелинейной фильтрации вблизи скважины, сопровождающегося притоком воды в ее ствол. Как показано в работе [Кочарян и др., 2011] такие эффекты могут возникать при наличии локаль- ных неоднородностей фильтрационных свойств водовмещающих пород, вскрытых скважиной.

Для описания повышений уровня воды (рис. 4) вследствие импульсного роста давления использовалась затухающая экспоненциальная функция, характеризующая процесс течения воды без конкретизации пространственного изменения поля давления, вызывающего приток воды в скважину [Roeloffs, 1998]:

$$
u(t)=u_{0}\left(1-\exp \left(-t / t_{r}\right)\right)
$$

где: $u_{0}$ - максимальная амплитуда повышения напора подземных вод; $t$ - время; $t_{r}$ - параметр времени релаксации давления в системе "скважинаводовмещающая порода”.

На рис. 11 представлены результаты расчета повышения уровня воды в скважине Ю3-5 в течение двух часов после вступления сейсмических волн при Олюторском землетрясении 20.04.2006 г., $M_{w}=7.6$ (№ 5 табл. 1, рис. 4). Расчетное повышение уровня воды хорошо согласуется с наблюденными данными при величине амплитуды увеличения напора $u_{0}=1.6$ см и времени релаксации давления $t_{r}=14$ мин. 

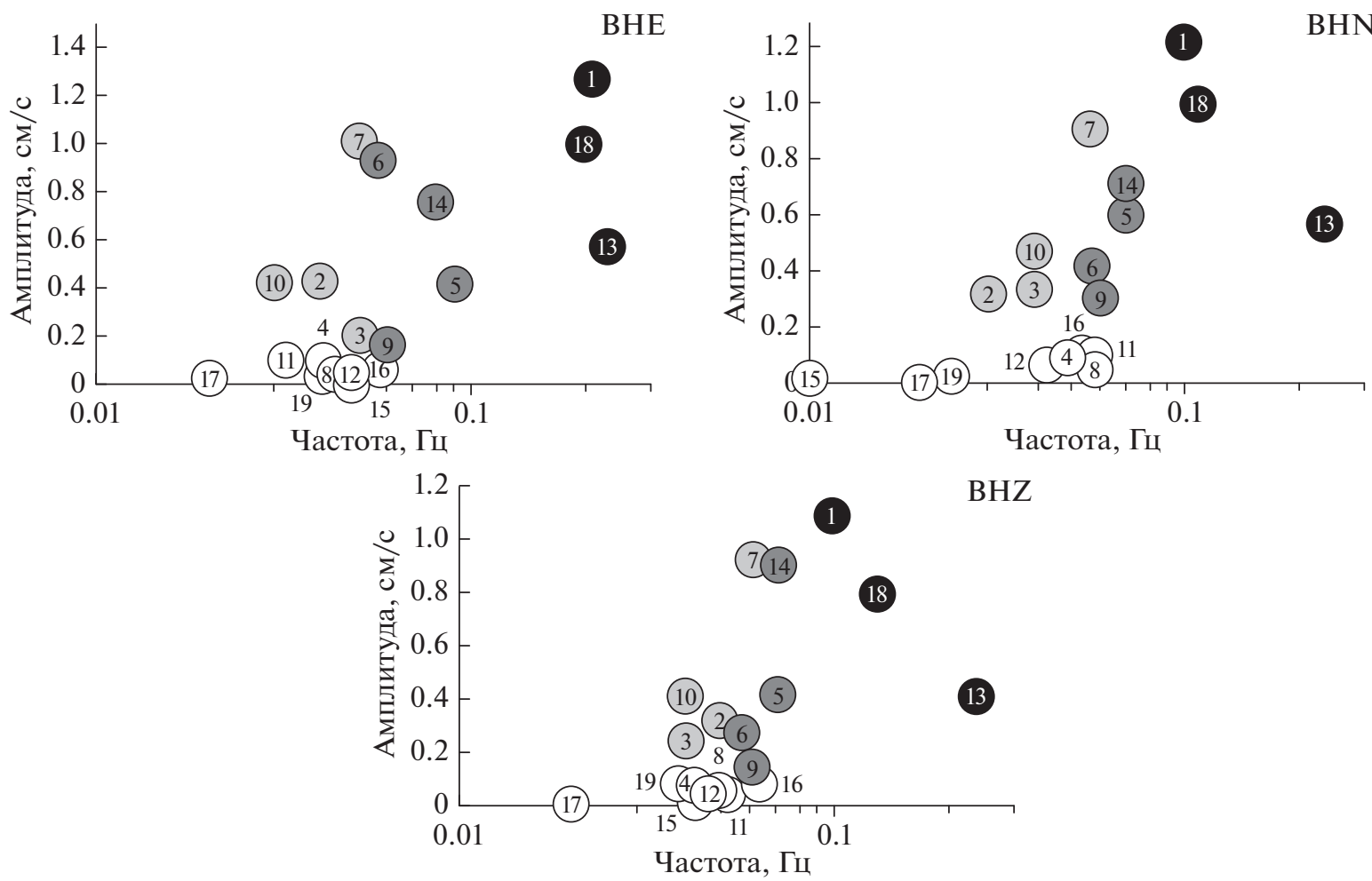

Рис. 9. Распределение ГГСВ различных типов (тип I - белые кружки, тип II - серые, тип III - темно-серые, тип IV черные) в зависимости от величин максимальной амплитуды скорости движения грунта на каналах BHE, BHN и BHZ, с/ст. РЕТ и центральной частоты ее проявления. Цифры - номера землетрясений из табл. 1, табл. 2 и рис. 1 , рис. $2-$ рис. 5.

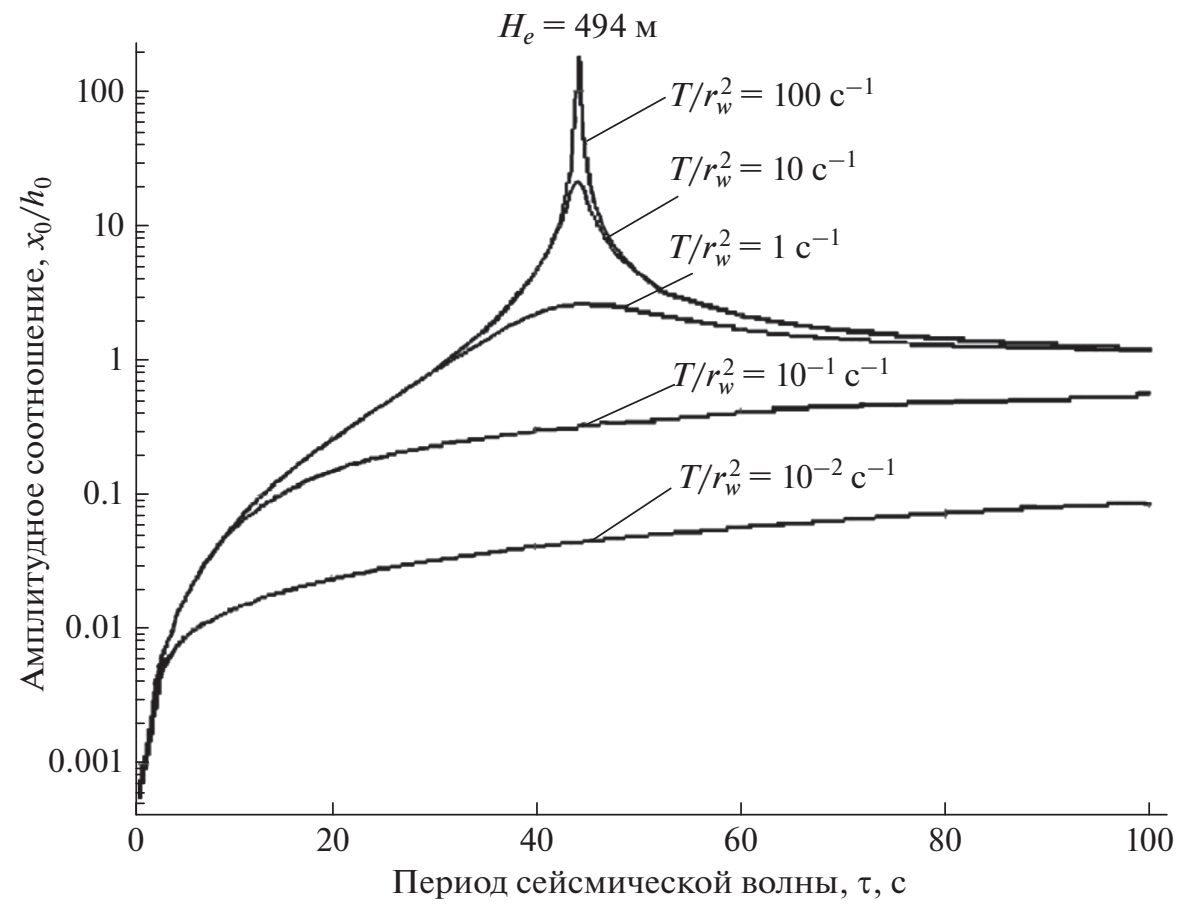

Рис. 10. Изменения амплитудного соотношения между вариациями уровня воды $x_{0}$ и напором подземных вод $h_{0}$ в зависимости от периода сейсмической волны $\tau$, величины коэффициента водопроводимости $T$ и радиуса скважины в области связи с водовмещающими породами $r_{w}$. 


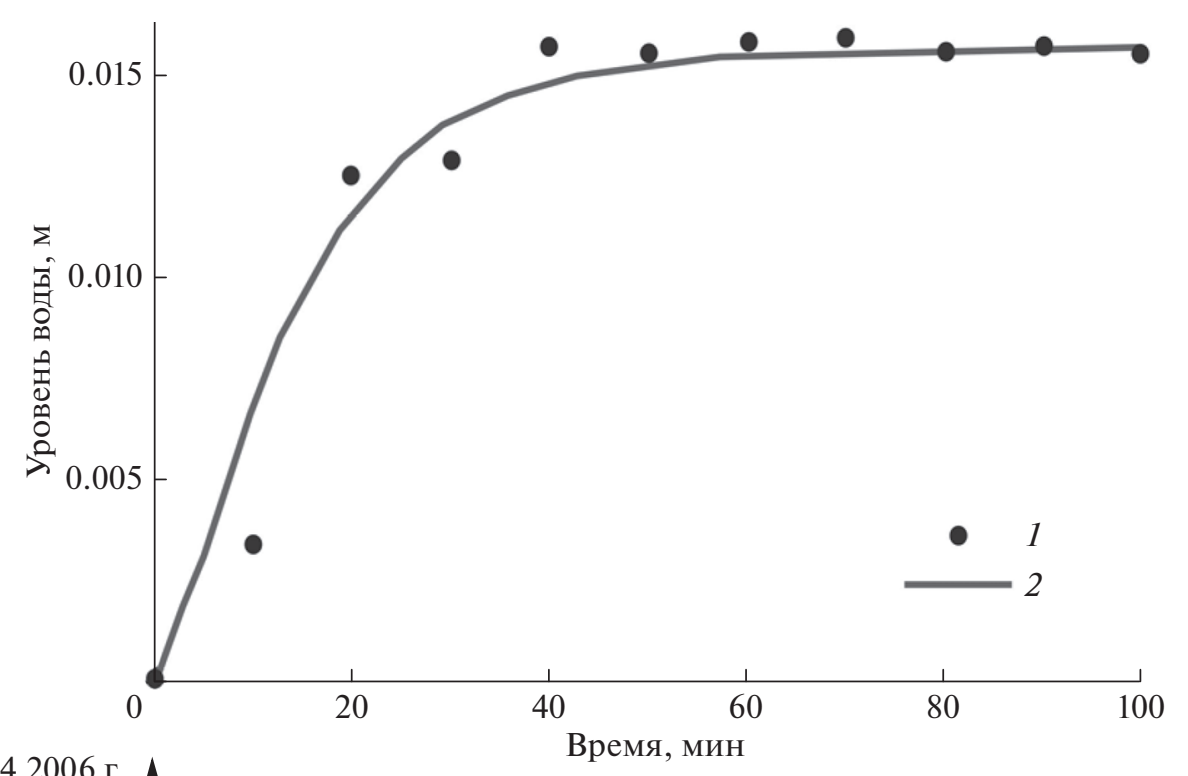

$$
\left.\begin{array}{c}
20.04 .2006 \text { г. } \\
M_{w}=7.6 \\
d_{e}=1018 \mathrm{KM}
\end{array}\right\} 23: 25
$$

Рис. 11. Повышение уровня воды в скважине Ю3-5 в течение двух часов после вступления сейсмических волн при Олюторском землетрясении 20.04.2006 г., $M_{w}=7.6$ (№ 5 табл. 1, показано стрелкой): 1 - 10-минутные данные наблюдений; 2 - расчетное повышение уровня воды по (6).

Длительные понижения уровня воды в результате сильных местных землетрясений (Тип IV ГГСВ, рис. 5) могут вызываться снижением напора подземных вод при локальном или площадном увеличении проницаемости водовмещающих пород при сейсмических сотрясениях с интенсивностью $I_{\text {msk-64 }} \geq 5$ баллов. Такие понижения уровня воды описываются математической моделью удаленного точечного источника возмушения напора в водоносном горизонте [Brodsky et al., 2003; Болдина, Копылова, 2010; 2013; 2017; Болдина, 2017]:

$$
x=x_{0}-\Delta h \operatorname{erfc}(R / \sqrt{4 c t}),
$$

где: $x$ - уровень воды в скважине; $x_{0}-$ начальный уровень воды в скважине; $R$ - расстояние от скважины до источника падения напора; $c$ - пьезопроводность; $t$ - длительность понижения уровня; $\operatorname{erfc}(x)$ - дополнение функции ошибки $\operatorname{erf}(x)$ до 1 , т.е. $\operatorname{erfc}(x)=1-\operatorname{erf}(x)=\frac{2}{\sqrt{\pi}} \int_{0}^{x} \exp \left(-u^{2}\right) d u$.

На рис. 12 представлены результаты расчета понижения уровня воды с амплитудой $\Delta h=0.40 \mathrm{м}$ в течение трех месяцев после Жупановского землетрясения 30.01.2016 г., $M_{w}=7.2$ (№ 18 табл. 1, рис. 5) по (7). Такое понижение уровня воды могло произойти при величине пьезопроводности водовмещающих пород $c=0.24 \mathrm{M}^{2} / \mathrm{c}$ и при расстоянии между скважиной и источником падения напора $R=450$ м [Болдина, Копылова, 2017; Болдина, 2017]. Расчеты понижений уровня воды по
(7) после Кроноцкого землетрясения 05.12.1997 г., $M_{w}=7.8$ (№ 1, рис. 5) и землетрясения 28.02.2013 г., $M_{w}=6.8$ (№ 13, рис. 5) согласуются с представленным выше результатом (рис. 12) в части оценки величины пьезопроводности водовмещающих пород и определения расстояния до источника падения напора. Во всех случаях величины расстояний до источника падения напора оказались одинаковыми $R=450$ м [Болдина, Копылова, 2010; 2013; 2017]. Это может указывать на то, что на расстоянии порядка 450 м от скважины расположен геологический объект, например, разломная зона или другой вид гидрогеологического “окна", водопроницаемость которого резко увеличивается при сейсмических сотрясениях интенсивностью 5 и более баллов по шкале MSK-64. Более обоснованные предположения о природе таких объектов и их поведении при сильных сейсмических сотрясениях, а также для уточнения строения среды в районе скважины Ю3-5, следует провести полевое обследование территории с привлечением геофизических методов.

\section{ОБСУЖДЕНИЕ РЕЗУЛЬТАТОВ И ВЫВОДЫ}

О типизации ГГСВ и ее обоснованности. В результате многолетних детальных наблюдений за вариациями уровня воды в скважине Ю3-5 были выделены четыре типа ГГСВ при воздействии сейсмических волн, излучаемых из очагов силь- 


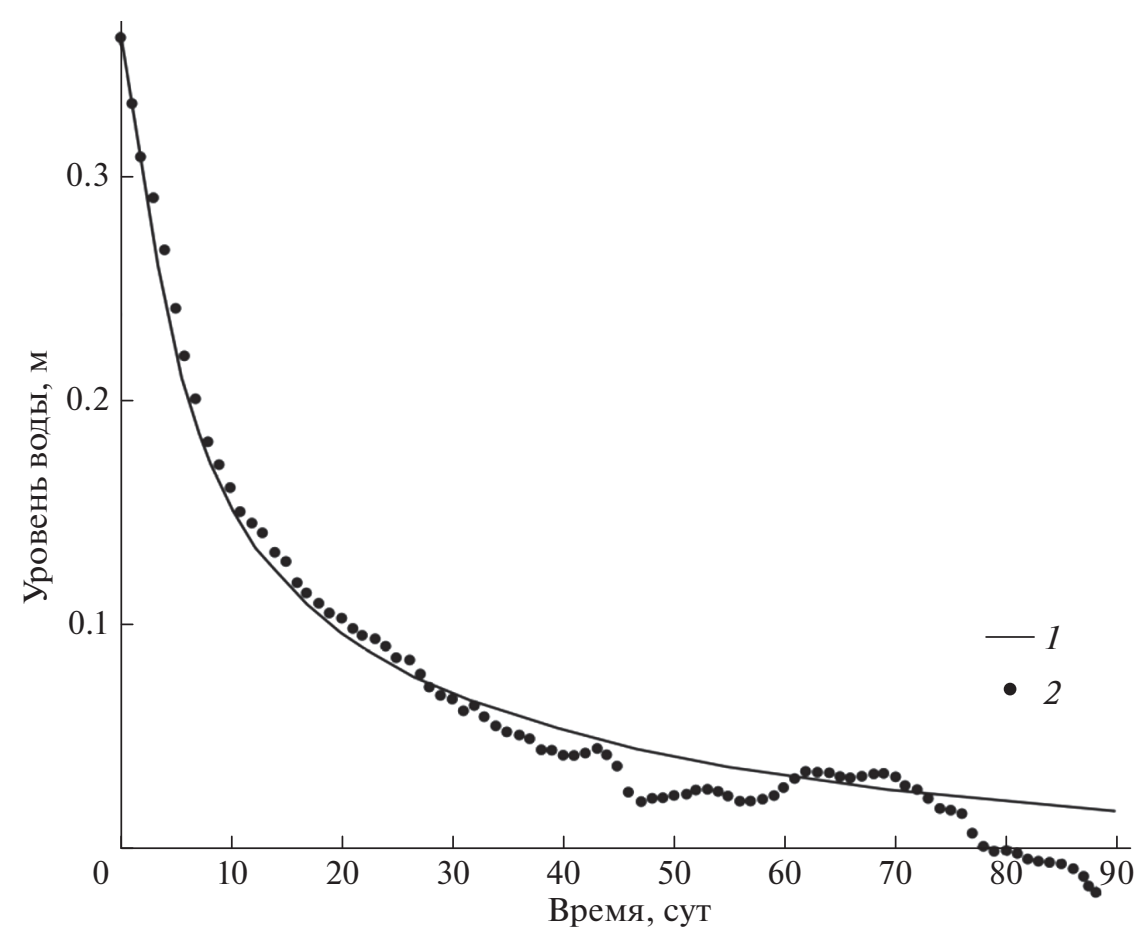

Рис. 12. Результаты моделирования понижения уровня воды в скважине ЮЗ-5 в течение трех месяцев после Жупановского землетрясения 30.01.2016 г., $M_{w}=7.2$ (№ 18 табл. 1): 1 - среднесуточные данные наблюдений с компенсированными барометрическими и сезонными вариациями; 2 - расчетное понижение уровня воды по (7).

ных местных и удаленных землетрясений. Такой результат получен благодаря обеспечению непрерывности и прецизионности уровнемерных наблюдений в течение длительного времени и применению для обработки и визуализации данных специализированных программных средств Информационной системы POLYGON [Копылова и др., 2009] и программы DIMAS [Дрознин, Дрознина, 2010], позволяющих анализировать изменения уровня воды в широком временном диапазоне (от минут до дней и месяцев) и сопоставлять выделенные ГГСВ с временами вступления различных групп сейсмических волн.

Вместе с тем, при периодичности изменений уровня воды 5-10 мин оказалось возможным получение лишь приблизительных оценок амплитуд и продолжительности колебаний уровня воды при проявлениях ГГСВ I и II типов (табл. 1). Несмотря на такой методический недостаток выделение ГГСВ I и II типов на основе используемых технических средств согласуется с данными высокочастотной регистрации давления в скважине Ю3-5 (рис. 6), а также с рассмотренными во Введении данными подобных наблюдений в других сейсмоактивных регионах на скважинах, вскрывающих скальные водовмещающие породы.

Представленный в настоящей работе опыт регистрации четырех различных типов ГГСВ в одной скважине является уникальным.
Перспективы дальнейшего исследования ГГСВ мы связываем с внедрением в практику работы технических средств регистрации давления подземных вод в скважинах с частотой не менее десятков Гц, соответствующей детальности сейсмометрических наблюдений.

О зависимости проявления ГГСВ различных типов от интенсивности сейсмического воздействия. На рис. 7а и 7б продемонстрировано, что проявление выделенных по морфологическим признакам четырех типов ГГСВ определяется параметрами землетрясений - соотношением магнитуды $M_{w}$ и эпицентрального расстояния $d_{e}$ землетрясения, а также величинами удельной плотности энергии в сейсмической волне $e$ и ее максимальной скорости $V_{m}$. Используемая совокупность количественных характеристик землетрясения может рассматриваться в качестве комплексного показателя интенсивности воздействия сейсмических волн, излучаемых из очага, на наблюдательную скважину. При возникновении сильного землетрясения на расстояниях до тысяч км от скважины, с использованием величин $M_{w}, d_{e}, e$ и $V_{m}$, можно прогнозировать характер развития ГГСВ в скважине Ю3-5, а также в других скважинах-аналогах, расширяя тем самым возможности метода уровнемерных наблюдений в системе геофизического мониторинга сейсмоактивных районов. 
Расчетный характер величин $e$ и $V_{m}$ предполагает их независимую проверку по отношению к скважине Ю3-5. В табл. 2 приводятся расчетные величины $V_{m}$ и оценки максимальных скоростей, зарегистрированных на каналах BHN, BHE, BHZ на с/ст. РЕT, которые хорошо согласуются между собой для большей части рассматриваемых землетрясений. Исключение составляют лишь наиболее сильные землетрясения (№№ 1, 10, 13, 14 и 18), для которых расчетные значения $V_{m}=3.2-13.9 \mathrm{~cm} / \mathrm{c}$ превышают зарегистрированные скорости на с/ст. РЕТ в несколько раз (до 10-ти). Это связано с особенностями работы велосиметров STS-1 в составе аппаратурного комплекса IRIS, для которых амплитудный диапазон ограничивается максимальной величиной скорости $1 \mathrm{~cm} / \mathrm{c}$.

К сожалению, мы не имеем возможности получить независимые оценки величин удельной плотности энергии в волне $e$ для района скважины Ю3-5.

Об особенностях гидрогеодинамических процессов в системе "скважина-водовмещающая порода" при воздействии сейсмических волн. Как показано выше, в зависимости от интенсивности сейсмического воздействия и амплитудно-частотного состава максимальных фаз движения грунта при прохождении сейсмических волн могут проявляться различные типы ГГСВ, обусловленные возникновением и развитием специфических гидрогеодинамических процессов в рассматриваемой системе "скважина-водовмещающая порода” (рис. 7, рис. 9). Рассмотрены несколько видов таких процессов:

1. Гармонические вариации давления подземных вод и движения столба воды в скважине рассмотрены с использованием математической модели [Cooper et al., 1965]. Осцилляции уровня воды в скважине Ю3-5 с амплитудами $\geq 0.5$ см возникают при воздействии поверхностных волн с величинами максимальных скоростей порядка $0.2-0.5 \mathrm{~cm} / \mathrm{c}$ на частотах 0.06-0.01 Гц (периоды от 16 до 100 с, рис. 9). Моделирование гидрогеодинамического процесса во время Суматра-Андаманского землетрясения (рис. 10) показало, что воздействие поверхностных волн на периоде 44.6 с, соответствующем резонансной частоте скважины, может сопровождаться усилением вариаций давления подземных вод в скважине и колебаниями уровня воды с амплитудами до единиц-первых десятков см в течение времени от часов до одних суток.

2. При увеличении скорости и частоты максимальных фаз сейсмического сигнала (типы II и III ГГСВ) вблизи ствола скважины возникает эффект импульсного увеличения напора подземных вод с амплитудами порядка первых см водяного столба.

3. При воздействии высокочастотных объемных волн от сильных местных землетрясений, со- провождающихся сотрясениями интенсивностью 5-6 баллов, происходит падение напора подземных вод с амплитудами до 0.1 бар на расстоянии до первых сотен м от скважины.

Приведенные примеры моделирования ГГСВ на основе известных математических моделей и данных о параметрах водовмещающих пород и конструкции скважины показывают возможность рассмотрения гидрогеодинамических процессов формирования различных типов ГГСВ в наблюдаемой системе "скважина-водовмещающая порода" с получением количественных критериев их инициации и развития.

В случае скважины Ю3-5, типы I и II ГГСВ возникают вследствие сотрясений ствола скважины, динамической деформации водовмещающих пород и гармонических колебаний давления подземных вод в системе "скважина-водовмещающая порода”. При прохождении поверхностных сейсмических волн с периодами, соответствующими резонансной частоте скважины ( $\approx 0.023$ Гц $)$ может возникать эффект усиления колебаний давления подземных вод в стволе скважины. Отметим, что нами не рассматривался возможный эффект возникновения осцилляций давления воды вследствие упругого изменения объема воды в скважине при воздействии сейсмических волн, который в последнее время рассматривается при интерпретации высокочастотных записей давления в закрытых скважинах, в частности, в работе [Shalev et al., 2017a].

Повышение уровня в течение десятков минутчасов после прохождения сейсмических волн (типы II и III ГГСВ) вызывается кратковременным ростом давления вследствие нарушения стационарных условий течения воды в области, непосредственно примыкающей к стволу скважины.

Длительное понижение уровня воды (тип IV ГГСВ) наблюдается после ощутимых землетрясений ( $I_{\mathrm{msk}-64} \geq 5$ баллов) и, по-видимому, вызывается увеличением проницаемости водовмещающих пород, которое сопровождается падением давления подземных вод с амплитудами 0.03-0.1 бар в радиусе порядка сотен метров от скважины. Такой вывод согласуется с данными работы [Zhang et al., 2018], в которой рассматривается понижение уровня воды в течение месяца в скважине МР, Китай, после землетрясения 12.05 .08 г. (№ 9 рис. 1, табл. 1) с использованием различных моделей гидродинамических процессов, каждая из которых формально давала хорошее соответствие между расчетными и наблюденными данными. Вместе с тем, авторы, основываясь на комплексном анализе результатов моделирования и привлечении данных о вариациях приливного отклика уровня воды в скважине МР, выделили механизм временного увеличения проницаемости водовмещающих пород в качестве наиболее правдоподоб- 
ного объяснения длительного постсейсмического понижения уровня воды.

Выполненный в настоящей работе анализ совокупности ко- и постсейсмических эффектов в изменениях уровня воды в скв. Ю3-5 показывает, что при воздействии сейсмических волн от сильных землетрясений в системе "скважина-водовмещающая порода" возникают специфические гидрогеодинамические процессы, сопровождающиеся вариациями напора подземных вод, эпизодами нелинейной фильтрации, локальными и площадными изменениями фильтрационных свойств водовмещающих пород, а также, возможно, изменениями состава подземной воды.

\section{БЛАГОДАРНОСТИ}

Авторы выражают благодарность Геологической службе Израиля (GSI) и лично директору Ривке Амит, начальнику отдела воды и природных ресурсов Ейялю Шалеву, научному сотруднику Владимиру Ляховскому и техническому сотруднику Халелю Лутски за предоставление аппаратуры для высокочастотной регистрации уровня воды в скважине Ю3-5 и полезные консультации по ее установке и эксплуатации.

\section{ФИНАНСИРОВАНИЕ РАБОТЫ}

Работа выполнена при финансовой поддержке РФФИ, проект 18-05-00337 “Типизация и модели гидрогеосейсмических эффектов землетрясений по данным уровнемерных наблюдений в скважинах (на примере Камчатского региона)".

\section{СПИСОК ЛИТЕРАТУРЫ}

Адушкин B.B., Спивак А.A. Физические поля в приповерхностной геофизике. М.: ГЕОС. 2014. 360 с.

Болдина C.В. Эффекты землетрясений в системе "скважина-водовмещающая порода". Дюссельдорф: LAP LAMBERT Academic Publishing RU. 2017. 209 c.

Болдина С.В., Копылова Г.Н. Моделирование гидрогеосейсмических вариаций уровня воды в скважине. Проблемы комплексного геофизического мониторинга Дальнего Востока России. Труды Второй региональной научно-технической конференции ПетропавловскКамчатский: 11-17 октября 2009 г. ПетропавловскКамчатский: ГС РАН. 2010. С. 166-170.

Болдина С.В., Копылова Г.Н. Моделирование вариаций уровня воды в скважине Ю3-5, Камчатка, вызванных землетрясением 28.02.2013 г., $M=6.8$. Проблемы комплексного геофизического мониторинга Дальнего Востока России. Труды Четвертой научно-технической конференции. Обнинск: ГС РАН. 2013. С. 435-439.

Болдина С.В., Копылова Г.Н. Эффекты Жупановского землетрясения 30.01 .2016 г., $M_{w}=7.2$, в изменениях уровня воды в скважинах Ю3-5 и Е-1, Камчатка // Геодинамика и тектонофизика. 2017. Т. 8. № 4. С. 863-880. https://doi.org/10.5800/GT-2017-8-4-0321
Дрознин Д.В., Дрознина С.Я. Интерактивная программа обработки сейсмических сигналов DIMAS // Сейсмические приборы. 2010. Т. 46. № 3 С. 22-34.

Касимова В.А., Копылова Г.Н. О зависимости вариаций уровня воды при сильнейших землетрясениях от амплитудно-частотного состава максимальных фаз движений грунта (на примере Ю3-5, Камчатка). Современные методы обработки и интерпретации сейсмологических данных. Материалы Седьмой Международной сейсмологической школы. Обнинск: ГС РАН. 2012. C. $143-147$.

Киссин И.Г. Гидрогеологический мониторинг земной коры // Физика Земли. 1993. № 8. С. 58-69.

Копылова Г.Н. Изменения уровня воды в скважине Елизовская-1, Камчатка, вызванные сильными землетрясениями (по данным наблюдений в 1987-1998 гг.) // Вулканология и сейсмология. 2001. № 2. С. 39-52.

Копылова Г.Н. Изменения уровня воды в скважине Ю3-5, Камчатка, вызванные землетрясениями // Вулканология и сейсмология. 2006. № 6. С. 52-64.

Копылова Г.Н. Оценка информативности уровнемерных наблюдений в скважинах для поиска гидрогеодинамических предвестников землетрясений (на примере Камчатки) // Геофизические исследования. 2009. T. 10. № 2. C. 56-68.

Копылова Г.Н., Болдина С.В. Оценка пороупругих параметров резервуаров подземных вод (по данным уровнемерных наблюдений на скважинах Ю3-5 и Е-1, Камчатка) // Вулканология и сейсмология. 2006. № 2. C. $17-28$.

Копылова Г.Н., Болдина С.В. Отклик уровня воды в скважине Ю3-5, Камчатка, на Суматра-Андаманское землетрясение 26 декабря 2004 г., $M=9.3$ // Вулканология и сейсмология. 2007. № 5. С. 39-48.

Копылова Г.Н., Болдина С.В. Гидрогеосейсмологические исследования на Камчатке: 1977-2017 гг. // Вулканология и сейсмология. 2019. № 2. С. 3-20.

Копылова Г.Н., Болдина С.В., Касимова В.А. Эффекты сильных землетрясений, $M_{w}=6.8-9.1$, в изменениях уровня воды в скважине Ю3-5, Камчатка. Проблемы комплексного геофизического мониторинга Дальнего Востока России. Труды Шестой научно-технической конференции. Петропавловск-Камчатский. 1-7 октября 2017 г. Обнинск: ФИЦ ЕГС РАН, 2017. С. 276-280.

Копылова Г.Н., Болдина С.В., Смирнов А.А., Чубарова Е.Г. Опыт регистрации вариаций уровня и физико-химических параметров подземных вод в пьезометрических скважинах, вызванных сильными землетрясениями (на примере Камчатки) // Сейсмические приборы. 2016. № 4. C. 43-56.

https://doi.org/10.21455/si2016.4-4

Копылова Г.Н., Болдина С.В., Смолина Н.Н., Сизова Е.Г., Касимова В.A. Гидрогеосейсмические вариации уровня воды в пьезометрических скважинах Камчатки (по данным наблюдений 1987-2011 гг.). Сейсмологические и геофизические исследования на Камчатке. К 50-летию детальных сейсмологических наблюдений / Под ред. Е.И. Гордеева, В.Н. Чеброва. ПетропавловскКамчатский: Новая книга. 2012. С. 236-269.

Копылова Г.Н., Иванов В.Ю., Касимова В.А. Разработка элементов информационной системы комплексных геофизических наблюдений на территории Камчатки // 
Российский журн. наук о Земле. 2009. T. 11. RE2002. https://doi.org/10.2205/2009ES000329

Копылова Г.Н., Куликов Г.В., Тимофеев В.М. Оценка состояния и перспективы развития гидрогеодеформационного мониторинга сейсмоактивных регионов России // Разведка и охрана недр. 2007. № 11. С. 75-83.

Копылова Г.Н., Стеблов Г.М., Болдина С.В., Сдельникова И.А. О возможности оценок косейсмической деформации по данным уровнемерных наблюдений в скважине // Физика Земли. 2010. № 1. С. 51-61.

https://doi.org/10.1134/S1069351310010040

Кочарян Г.Г., Виноградов Е.А., Горбунова Э.М., Марков В.К., Перник Л.М. Гидрогеологический отклик подземных коллекторов на сейсмические колебания // Физика Земли. 2011. № 12. С. 50-62. https://doi.org/10.1134/S1069351311120068

Кочарян Г.Г., Марков В.К., Марков Д.В., Перник Л.М. О механизме вариаций флюидодинамического режима подземных коллекторов под действием слабых возмущений. Физические поля и динамика взаимодействующих геосфер. Сборник научных трудов ИДГ РАН. М.: ГЕОС. 2007. С. 56-65.

Левина В.И., Гусев А.А., Павлов В.М. и др. Кроноцкое землетрясение 5 декабря 1997 г. с $M_{w}=7.8, I_{0}=8$ (Камчатка). Землетрясения Северной Евразии в 1997 г. Обнинск: ГС РАН. 2003. С. 251-271.

Ризниченко Ю.В. Размеры очага корового землетрясения и сейсмический момент. Исследования по физике землетрясений. М.: Наука. 1976. С. 9-27.

Besedina A., Vinogradov E., Gorbunova E., Svintsov I. Chilean earthquakes: Aquifer responses at the Russian platform // Pure and Applied Geophysics. 2016. V. 173. P. 1039-1050. https://doi.org/10.1007/s00024-016-1256-5

Bower D., Heaton $K$. Response of an aquifer near Ottawa to tidal forcing and the Alaskan earthquake of 1964 // Can. J. Earth Sci. 1978. V. 15. P. 331-340.

Brodsky E.E., Roeloffs E., Woodcock D., Gall I., Manga M.A. A Mechanism for sustained groundwater pressure changes induced by distant earthquakes // J. Geophysical Research. 2003. V. 108. P. 2390-2400.

https://doi.org/10.1029/2002JB002321

Chelidze T., Melikadze G., Kobzev G., Shengelia I., Jorjiashvili N., Mepharidze E. Hydrodynamic and seismic response to teleseismic waves of strong remote earthquakes in Caucasus// Acta Geophysica, 2019. V. 67. P. 1-16.

https://doi.org/10.1007/s11600-018-00241-7

Chia Y., Chiu J.-J., Chiang Y.-H., Lee T.-P., Wu Y.-M., Horng M.-J. Implications of coseismic groundwater level changes observed at multiple-well monitoring stations // Geophys. J. Int. 2008. V. 172. P. 293-301.

https://doi.org/10.1111/j.1365-246X.2007.03628.x

Cooper H.H., Bredehoeft J.D., Papadopulos I.S., Bennet R.R. The response of well-aquifer system to seismic waves // J. Geophysical Research. 1965. V. 70. P. 3915-3926.

Gomberg J., Felzer K., Brodsky E. Earthquake Dynamic Triggering and Ground Motion Scaling. Proc. of 4th International Workshop on Statistical Seismology. 9-13 January, 2006. Kanagawa, Japan. P. 45-51.

Kanamori H., Brodsky E.E. The physics of earthquakes // Rep. Prog. Phys. 2004. V. 67. P. 1429-1496.

Kopylova G.N., Boldina S.V., Smirnov A.A., Chubarova E.G. Experience in Registration of Variations Caused by Strong
Earthquakes in the Level and Physicochemical Parameters of Ground Waters in the Piezometric Wells: the Case of Kamchatka // Seismic Instruments. 2017. V. 53. №. 4. P. 286-295. https://doi.org/10.3103/S0747923917040065

Matsumoto N., Roeloffs E.A. Hydrological response to earthquakes in the Haibara well, central Japan: II. Possible mechanism inferred from time-varying hydraulic properties // Geophys. J. Int. 2003. V. 155. P. 899-913.

Roeloffs E.A. Persistent water level changes in a well near Parkfield, California, due to local and distant earthquakes // J. Geophysical Research. 1998. V. 103. № B1. P. 869-889.

The Monitoring and Forecasting Department of China Earthquake Administration. Theoretical basis observation techniques of seismic underground fluids. Beijing: Seismology Press, 2007. P. 98-110.

Shalev E., Kurzon I., Doan M.-L., Lyakhovsky V. Water-level oscillations caused by volumetric and deviatoric dynamic strains // Geophys. J. Int. 2016a. V. 204. P. 841-851. https://doi.org/10.1093/gji/ggv483

Shalev E., Kurzon I., Doan M.-L., Lyakhovsky V. Sustained water-level changes caused by damage and compaction induced by teleseismic earthquakes // J. Geophys. Res. Solid Earth. 2016b. V. 121. P. 4943-4954.

https://doi.org/10.1002/2016JB013068

Shi Zh., Wang G., Liu C. Co-seismic groundwater level changes induced by the May 12, 2008 Wenchuan earthquake in the near field // Pure Appl. Geophys. 2013. V. 170. P. 1773-1783.

https://doi.org/10.1007/s00024-012-0606-1

Shi Zh., Wang G., Manga M., Wang C.-Y. Mechanism of coseismic water level change following four great earthquakes insights from co-seismic responses throughout the Chinese mainland. Earth and Planetary Science Letters. 2015. V. 430. P. 66-74.

https://doi.org/10.1016/j.epsl.2015.08.012

Sun $X$., Liu $Y$. Changes in groundwater level and temperature induced by distant earthquakes // Geosciences J. 2012. V. 16. №. 3. P. 327-337. https://doi.org/10.1007/s12303-012-0022-7

Sun X., Wang G., Yang X. Coseismic response of water level in Changping well, China, to the $M_{w} 9.0$ Tohoku earthquake // J. Hydrology. 2015. V. 531. P. 1028-1039. https://doi.org/10.1016/j.jhydrol.2015.11.005

Wakita $H$. Water wells as possible indicators of tectonic strain // Science. 1975. V. 189. P. 553-555.

Wang C.-Y., Manga M. Earthquakes and Water. Lecture Notes in Earth Sciences 114. Springer, Berlin, 2010. 249 p. https://doi.org/10.1007/978-3-642-00810-8

Wang C., Cheng L.H., Chin C.V., Yu S.B. Coseismic hydrologic response of an alluvial fan to the $1999 \mathrm{Chi}-\mathrm{Chi}$ earthquake, Taiwan // Geology. 2001. V. 29(9). P. 831-834.

Weingarten M., Ge S. Insights into water level response to seismic waves: a 24-year high-fidelity record of global seismicity at Devils Hole // Geophys. Res. Lett., 2014. V. 41. P. 75-80

Zhang Sh., Shi Zh., Wang G., Zhang Zh. Quantitative Assessment of the Mechanisms of Earthquake-Induced Groundwater-Level Change in the MP Well, Three Gorges Area // Pure Appl. Geophys. 2018. V. 175 (7). P. 2475-2484.

https://doi.org/10.1007/s00024-017-1643-6 


\title{
Effects of Seismic Waves in Water Level Variations in a Well: Empirical Data and Models
}

\author{
G. N. Kopylova ${ }^{a, *}$ and S. V. Boldina ${ }^{a, * *}$ \\ ${ }^{a}$ Kamchatka Branch, Federal Research Center "Geophysical Survey of the Russian Academy of Sciences", \\ Petropavlovsk-Kamchatskii, 683006 Russia \\ *e-mail: gala@emsd.ru \\ **e-mail: boldina@emsd.ru
}

The high-precision water level measurements with a time interval of 5-10 min were carried out in 1996-2017 in the YuZ-5 well, Kamchatka. In the obtained time series, water level variations caused by the passage of seismic waves (hydrogeoseismic variations-HGSV) during 19 earthquakes with $M_{w}=6.8-9.1$ that occurred at the epicentral distances of 80-14.6 thousand $\mathrm{km}$ are identified. Based on the HGSV morphological features, four main types of these variations are distinguished: oscillations (I); short (up to tens of hours) rises (II) in the water level superimposed on the fluctuations; short rises (III); and long (1.5-3 months) falls in the water level ( IV). The dependence of the occurrence of the revealed GHSV types on the earthquakes' parameters (magnitude and distance), on the specific energy density and maximum velocities of seismic waves, and on the amplitude-frequency content of ground motion according to the records at the nearest seismic station is considered. Hydrogeodynamic processes of HGSV formation are analyzed by several examples using numerical modeling. It is shown that the forced and free fluctuations amplitude in the water level amplitude (types I and II) can arise due to the intensification of the groundwater pressure variations in the well-water-bearing rock system during the passage of surface seismic waves with the periods corresponding to the resonant frequency of the well $(\tau=44.6 \mathrm{~s})$. The rise in the water level in well lasting for tens of minutes to hours (HGSV variation types II and III) is due to the short increase in pressure when the steady state of water flow in the direct vicinity of the well is violated; the strong local earthquakes accompanied by ground shaking with intensity $I_{\text {msk-64 }} \geq 5$ cause long falls in the water level (type IV) due to pressure drop with amplitudes up to 0.1 bar within a radius up to several hundred meters from the well.

Keywords: hydrogeoseismic variations, amplitude-frequency content of ground motion 